\title{
Board compensation and disclosure quality: Corporate governance interference
}

\author{
Compensación de la junta y calidad de la divulgación: interferencia del \\ gobierno corporativo
}

\author{
Mahdi Salehi $^{1 *}$, Bahman Jamalikazemini ${ }^{2}$, Shayan Farhangdoust ${ }^{2}$ \\ ${ }^{1}$ Ferdowsi University of Mashhad, Iran \\ ${ }^{2}$ Imamreza International University of Mashhad, Iran
}

Received 31 August 2017; Accepted 29 May 2018

Available online 27 September 2018

\begin{abstract}
This paper investigates the impact of financial information disclosure quality on board compensation in various corporate governance mechanisms in Iran. A unique data set from a sample of 176 Iranian listed firms over the period 2010-2016 is used in order to address the following questions: as an incentive mechanism for managers, is there any relationship between compensation and disclosure quality of financial information while some corporate governance factors are interfered? Duality on board, educated members, females, and independent members are the aspects that are considered as corporate governance interference. Along with these issues, we investigate whether firm complexity is likely to affect the mentioned relationship. We find that corporate governance mechanisms including educated board members, independent members, females, and board members duality are not some reward-enhancing methods. This lends support to the conjecture that directors neglect the quality of information they provide, and as a consequence, they adjust their bonuses via other methods. Our findings indicate that there is a significant and positive relationship between board compensation and disclosure quality in firms which have complex activities and foreign sales. Finally, we indicate that disclosure quality has no significant impact on compensation in firms which have complex activity of controlling some subsidiaries.
\end{abstract}

JEL classification: J30, G30, G34, M12.

Keywords: Board Compensation; Disclosure quality; Corporate governance; Tehran stock exchange.

\footnotetext{
*Corresponding author.

E-mail address: mehdi.salehi@um.ac.ir (M. Salehi)

Peer Review under the responsibility of Universidad Nacional Autónoma de México.
} 


\section{Resumen}

Este documento investiga el impacto de la calidad de divulgación de información financiera a bordo de la compensación en varios mecanismos de gobierno corporativo en Irán. Se utiliza un conjunto de datos único de una muestra de 176 empresas iraníes incluidas en la lista durante el período 2010-2016 para abordar las siguientes preguntas: como mecanismo de incentivos para los gerentes, ¿existe alguna relación entre la compensación y la calidad de la información financiera revelada mientras que algunas empresas factores de gobernanza son interferidos? La dualidad a bordo, los miembros educados, las mujeres y los miembros independientes son los aspectos que se consideran interferencia de gobierno corporativo. Junto con estos problemas, investigamos si es probable que la complejidad de la empresa afecte la relación mencionada. Encontramos que los mecanismos de gobierno corporativo, incluidos los miembros del consejo educado, los miembros independientes, las mujeres y la dualidad de los miembros del consejo, no son algunos de los métodos que mejoran la recompensa. Esto respalda la conjetura de que los directores descuidan la calidad de la información que brindan y, como consecuencia, ajustan sus bonificaciones a través de otros métodos. Nuestros hallazgos indican que existe una relación significativa y positiva entre la remuneración de la junta y la calidad de la divulgación en las empresas que tienen actividades complejas y ventas en el extranjero. Finalmente, indicamos que la calidad de la divulgación no tiene un impacto significativo en la compensación en las empresas que tienen una actividad compleja de controlar algunas subsidiarias.

Códigos JEL: J30, G30, G34, M12.

Palabras clave: Compensación de la Junta; Calidad de divulgación; Gobierno corporativo; Bolsa de Teherán.

\section{Introduction}

With the emergence of large enterprises and the boom in economic activities, owners handed the duty of controlling companies' resources to professional managers. If managers receive appropriate feedback from their efforts, they will exert their maximum efforts in line with companies' activities - the owners' resources -. Therefore, in order to maximize their own benefits, owners had to compensate managers' efforts (Duong \& Evans, 2015; Feng et al., 2015). According to the agency theory and findings of Mirrlees (1976), Grossman \& Hart (1983), and Duong \& Evans (2015), if conflict of interest exists, managers usually put high priority on their own interests and neglect the shareholders'. Therefore, shareholders face some difficulties here: how to provoke managers to do their work better, and how to plan to conduct these activities in line with the firm's benefits. In order to address these issues, suitable criteria should be considered to gauge the managers' performance. Then, appropriate incentive schemes need to become connected to these criteria to align the managers' benefits and the owners'. If we consider the managers' performance and owners' benefits, it is in a way that adequate compensation is paid to the managers based on their efforts, and consequently, both groups' interests are increased. To pay sufficient rewards to the managers, their performance and efforts should be precisely evaluated (Hui \& Matsunaga, 2015). Taking into account the financial resources which are given by the owners to the managers for the firms' activities, and considering the financial statements of firms as the indicator of their performance results, Hui \& Matsunaga (2015) are of the opinion that financial statements and their quality are some of the most important and determining factors for the users. Also, they are suitable standards by which managerial efforts could be compensated. As noted by Bouckova (2015), the main 
role of financial reporting is the transfer of information to external users in an efficacious way. Timeliness, reliability, transparency, and comparability of information are the most important elements for informed economic decisions. Therefore, an effective decision is the one which is based on correct predictions. In this regard, the quality and the quantity of information reported in financial statements or in the explanatory notes - which are used to help decision makers are set to be the disclosure quality of financial information. These vital information provides a detailed description of financial condition and performance results of firms (Bouckova, 2015). As agency theory argues that conflict of interests is resulted from the separation of ownership and management, the managers' compensation creates a balance between the managers' benefits and the shareholders' (Kapopoulos \& Lazaretou, 2007; Bouckova, 2015). Although observations show that firms profits - as a measure for paying compensation - have diminished, but the bonuses are still being paid continuously.

Although growing literature on the board compensation and its effects on various aspects of corporations is seen, there is hardly any evidence on the relationship between board compensation and disclosure quality in various corporate governance mechanisms, especially in developing countries. By using data from Iranian listed firms, we look into this argument. Iran has some interesting aspects to explore this research. First, there is a notable method for categorizing firms in Iran; all listed firms are scored and ranked according to the timeliness and reliability of their information. Second, the mechanisms by which rewards are paid are varied and twisted in some ways. Third, the economic and financial situation of Iran in the MiddleEast and especially among developing countries make our sample truly engrossing. Among many identified criteria in Iran and in most countries, the quality of financial information is introduced and examined in this study. Although many people tend to buy and sell shares based on the financial statements, some detailed information such as corporate governance mechanisms are reported voluntarily. However, for a better information divulgence needed by the users, all specific data in every aspects should be included. We aim to investigate the relationship between board compensation and disclosure quality in the presence of various corporate governance mechanisms: duality, education degree and level, female on board, and independent executives. Last, but not the least, we will conclude our study on the mentioned relationships by including export and segment variables.

We contribute to the literature in several ways. We add to the corporate governance literature, compensation and disclosure quality research. Common belief has considered the use of routine criteria to compensate managers' endeavor. But it has not considered disclosure quality as a vital-determinant criterion, especially among different corporate governance conditions. Moreover, to our knowledge, the evidence on the relationship between disclosure quality and board compensation under various corporate governance mechanisms is still lacking in developing countries, and, consequently, we aim to fill this gap in the literature. Finally, some policy implications are provided by our study with respect to legislators' focuses on disclosure quality in that we argue that firms do not pay rewards based on the quality of reported information although they are of interest to shareholders. Hence, our study provides new insights into how disclosure quality is neglected in developing countries.

The remainder of the paper proceeds as follows: next part is the literature review and hypotheses development. Then comes the research design and sample selection process. The descriptive statistics are presented subsequently. The next section includes test results. And the final part concludes the paper. 


\section{Theoretical framework}

\section{Transparency and quality of financial information}

In order to make proper investment decisions, the users of financial information need accurate and timely data (Behrouzi et al., 2013). When firms report information which lacks transparency, they encounter credit risk and lose shareholders' faith. This situation substantially lessens the liquidity and reliability in the capital market. Indeed, the main reason behind capital markets' boom in long term is the environment in which divulged information is transparent (Madhani, 2009). Appropriate disclosure and information transparency have more positive impacts including information asymmetry reduction (Petersen \& Plenborg, 2006; Barth et al., 2013), stock liquidity increase (Bloomfield \& Wilks, 2000; Goh et al., 2008), firm values enhancement (Hassan et al., 2009), and earnings management reduction. Disclosure on dictionary means unfolding the information. By means of Kohler's dictionary, a clear show of a fact or condition on financial statements, explanatory notes, and audit reports is considered as disclosure. Market participants are always seeking high quality information because of their capabilities in reducing the information asymmetry between managers and investors. Several studies in the accounting literature illustrate that higher disclosure quality alleviates the information asymmetry. According to the findings of Francis et al. (2005), extensive disclosure policy is a mechanism for diminishing information asymmetry. Glosten \& Milgram (1985) argue that the higher disclosure quality results in the lower information asymmetry. Welker (1995) declare that in proportion to the disclosure level, information asymmetry and market liquidity go lower and higher respectively. Lang \& Lundholm (1996) contend that firms pursuing informative disclosure strategies are more followed by consistent analysts, have less variances in analysts' forecasts, and have more accurate profit forecasts. Also, according to the findings of Kim et al. (2008), there is a negative relationship between information asymmetry and disclosure quality andan increase in disclosure transparency can aid investors to evaluate earnings management.

The financial information disclosure may palliate agency costs. Information which is gathered by directors for their own use and had put little costs on them (Jensen \& Meckling, 1976). The mechanical theory which was introduced in the 1960s suggest that except for the firms' financial statements, the users of financial information do not use other source of information, and investors merely make their decisions based on the values which are reflected in the financial information. Based on this theory, Welker (1995) argues that investors may be systematically misled by the options and the accounting methods. On the other hand is the efficient market theory which indicates that all of the available information are fully reflected by the market values. In the semi-strong form of the efficient market theory, Welker (1995) demonstrated that fake accounting changes could be detected by the market, and managers cannot systematically mislead the market by using such changes. Ball et al. (2000) and Kothari (2000) perceive the transparency as a combination of timeliness and conservatism aspects. Lang \& Lundholm (1996) argued that higher disclosure quality via information asymmetry diminishes the surprises about a firm's performance, decreases stock price volatility, increases stock exchange rate, and enhances firms' performance. Bushman \& Smith (2003) also carried the conviction that reliable and effective accounting information facilitate shareholders' monitoring condition and law enforcement that protect shareholders' interests.

One of the most underlying factors behind sustainable economic development in any 
country is the provision of basic infrastructure for attracting domestic and foreign investments. This is acquired by a healthy-competitive environment having transparent and timely information where all the users have access to this information (Billings \& Capie, 2009). Nowadays, information transparency and disclosure quality are the main concerns of capital market participants all around the world (World Bank, 1998). Barth \& Schipper (2008) are of the opinion that transparent financial reporting is about the financial reports which unfold firms' main economic affairs in a way that users can easily understand them. Bushman et al. (2004) contend that in different economies, information transparency is considered as the power of extensive access to relevant and reliable information related to financial performance, investment opportunities, sovereignty, value, and risk taking of firms.

In the wake of the financial crisis in the Iran's capital market in early 2004, investors focused more on information transparency of the listed firms. In this regard, in addition to creating a balance between national and international standards, the Tehran Securities and Exchange Organization (TSEO) has exerted some efforts to enhance disclosure procedures. The provision of disclosure guidelines and introduction of a disclosure ranking system can be named as examples of these efforts.

On the one hand, disclosure quality and information transparency assure minor shareholders about receiving reliable information, and also assure them that the major shareholders are not trying to violate their rights. On the other hand, they provoke directors to attempt to improve corporate value instead of increasing their short-term self-interests. If directors keep private information for themselves, this will lead to information asymmetry and moral hazards (Barnea et al., 1985). Healy \& Palepu (2001) argue that firms are able to palliate agency conflicts and information asymmetry by financial reporting and divulging information. Therefore, the quality of investment decision is affected by disclosure quality. The potential benefits of disclosure and transparency consist of lower capital expenditure (Botoson, 1997; Diamond \& Verrocchia, 1991), agency costs reduction (Leftwich et al., 1981), stock price enhancement (Lang \& Lundholm, 2000; Gelb \& Zarowin, 2002) and firms' value augmentation. Sufficient information disclosure by firms helps users in finding suitable investment positions, and as a result, capital flows to the most productive firms. Navissi et al. (2016) examined the impact of various business strategies on managers' compensation and investment decisions. They showed that defensive or active strategies lead to different kinds of decisions, monitoring and investment level which have an impact on the managers' decisions and their bonuses. The results illustrated that firms with active (defensive) strategies have high (low) investment level. They also indicated that the pursued strategies by firms resulted in poor performance. Moreover, the high (low) level of investments are intensified in the presence of stock- (cash) based compensation and an active (defensive) policy employment. Choi (2014) investigated if the labor market competitiveness makes compensation contracts being adjusted. He found out that compensation offers will create confidence in employees and increase their efforts. He also showed that the initial outcomes of compensations are immense, and with the passage of time, these effects and the level of mutual trust will be different. Chen et al. (2015) examined the directors' concerns about their future rewards. They came to a conclusion that since directors can exert more efforts to prove their abilities, they are able to have an effect on rewards. They also showed that managers are very concerned about their fame. Boo et al. (2016) examined the impact of business connections and incentive schemes on the auditors biased reports. They concluded that with the presence of an incentive scheme, auditors' discrimination is likely to be reduced. 
Bratten \& Xue (2016) examined the relationship between institutional ownership and stockbased rewards. They found that firms with high institutional ownership have high abnormal incentives, experience noticeable decrease in rewards given to the CEOs. Cadman \& Sunder (2014) studied the relationship between CEOs' bonuses and shareholders' investment viewpoint. They declared that by the time shareholders are eager to sell their shares, they trigger short-term motivations in directors to maximize current share values. Kelly \& Seow (2016) investigated the pays to CEOs in comparison with the industries' median. They demonstrated that too high disclosure in industries cause marginally reductions in the understanding of rewards' fairness. Bushman et al. (2016) investigated the variance of directors' rewards and performance. They found out that when the dispersion of bonuses is very low (high), performance is improving (deteriorating). Pfeiffer \& Shields (2015) examined the reflected reaction of stock price to compensation contracts. They concluded that contrary to the expectations, directors choose contracts according to their private information and these choices have an effect on stock prices. Hogan \& Jonas (2016) examined the structure of compensation payment and transparency of financial statements restatement. The results illustrated that the growth in bonus paid to the managers in form of stocks reduces the transparency of disclosure quality. Their findings totally demonstrated that the compensation payment structure has an effect on information transparency. Brown \& Popova (2016) studied the relationship between managers' incentives and audit committee connections and its impact on auditors' decisions. They proved that the more directors' bonuses are, there will be more additional and unconventional relationships of audit committee and it will have greater impact on auditors' decisions.

\section{Compensation vis-a-vis disclosure quality}

With the emergence of big enterprises and booming businesses, shareholders put the burden of controlling firm's resources on expert directors. If the directors get valuable feedbacks on their efforts, they will exert their maximum efforts in order to maximize shareholders' wealth and enhance firms' performance. Thus, at least, shareholders are necessarily forced to consider some kind of bonuses to compensate managers' efforts and consequently, heighten their own benefits (Duong \& Evans, 2015; Feng et al., 2015). Since stock-based benefits given to the directors' act as some motivational factors to improve firm's value (Core \& Guay, 1999), agency theory shows that efficient bonus contracts which are based on firm performance criteria reduce the risk cost (Banker \& Datar, 1989; Bushman \& Indjejikian, 1993; Sloan, 1993). An effective performance criteria demonstrates the appropriateness of the managers' activities; activities that are related with the given compensations. Traditional agency theory considers that an efficacious market performs under the condition in which directors earn salaries based on the final output of their firms' activities. Labor market considers managers' abilities to determine their salaries. If firms consider their final output - products - as a criterion for managers' performance, salaries are adjusted based on that criterion. If preparation and diffusion of financial information are costly for firms, then, managers' bonus should be based on the disclosure quality of financial information. Regarding that all firms' forces - internal and external - can aid managers enhancing the quality of financial information disclosure.

Prior studies consider that high disclosure quality makes firms' values increasing by capital cost decrease (Botoson, 1997; Easley \& O'hara, 2004; Franciset al., 2008), litigation risks decrease (Franciset al., 1994) and investments development (Bushman \& Smith, 2001; 
Biddle \& Hilary, 2006). Diamond \& Verrocchia (1991) contend that regarding the correlation between disclosure quality and firm value, higher disclosure quality through an increase in stock liquidity leads to capital cost reduction. Botoson (1997) offered some evidence showing that high quality disclosure - via annual financial statements - decreases a firm's cost of capital. There is also some more evidence showed by Francis et al. (2004) declaring that there is a negative relationship between the quality of discretionary accruals and capital cost. In another study, Easley \& O'hara (2004) indicated that information risk is costly and it is related with high expected returns. Moreover, high quality disclosure results in an increase in cash flows by higher efficacious investments (Bushman \& Smith, 2001; Biddle \& Hilary, 2006). This has happened due to the additional transparency offered to external users which leads to better understanding of poor investments. Furthermore, monitoring a firm's performances may lead to agency costs reduction and may encourage directors to investment better.

The provision of high quality information is dependent on the managers' high understanding of economy, environment and competitive infrastructure of companies and industries, and also to the forthcomings which companies need to succeed in. Due to the high importance of directors' capabilities in following strategies, the financial information disclosure quality would be a demonstrative factor of administrative skills in promoting a firm's value (Chang et al., 2010). Actually, disclosure quality of financial information causes directors' salaries being adjusted in the labor market, representing a positive relationship between the two-mentioned variables. Adams \& Hossain (1998), and Cheng \& Courtenay (2006), declared a positive relationship between board compensation and voluntary disclosure. Also, a negative correlation was found between the variables by Abdelsalam \& Street (2007), and Eng \& Mak (2003). Since the provision of high quality information is costly for directors, and in case they may not have enough incentives, they will not exert sufficient effort in order to improve the information quality. Consequently, information with the quality of lower than normal will be produced. The cost by which information is produced include collecting, analyzing and transmitting. Higher disclosure quality via transparency augmentation makes directors being close to each other, therefore, they adjust the provision of information spontaneously. For instance, high quality disclosure decreases the directors' desires about following self-interest policies via disclosing adjusted information (Aboody \& Kasznik, 2000). Therefore, better disclosure quality reduces directors' opportunistic behavior on financial reports, and particularly, in the expropriation of wealth to themselves.

\section{Hypotheses development}

Corporate governance stands alone as a resolution to the conflict of interests. Shleifer \& Robert (1997) regard corporate governance as a guarantee for investment profitability of capital suppliers. The importance of corporate governance came up when the separation between directors and owners appeared (Epps \& Cereola, 2008; Zubaidah et al., 2009). The provision of high-quality information needs directors' deep conception of the economic and competitive environment in which a firm is performing and striving to be successful. According to the skills needed in following various policies, disclosure quality represents directors' abilities in enhancing firms' values (Chang et al., 2010). Managers, who are in the limelight, attempt to relieve the agency costs by publishing financial information. But in terms of tunneling, some directors use earnings management leverage to distort firms' actual operations and transfer 
shareholders' wealth to themselves (Shin \& Park, 1999; Chang \& Hong, 2000; Johnson et al., 2000; Bazrafshan et al., 2015). They do this either for receiving compensation or maintaining their desired niche (Biedleman, 1973; Tucker \& Zarovin, 2006).

To date, there has been a large body of research on the impact of corporate governance and managerial incentives on disclosure quality (Bushee \& Noe, 2000; Nagar et al., 2003; Ajinkya et al., 2005; Karamanou \& Vafeas, 2005; Anderson et al., 2009; Lee et al., 2012). According to Bear et al. (2010), many researches are conducted on the alternative or complementary role of corporate governance and disclosure quality, which some of them illustrated that in order to get higher disclosure quality, higher bonuses are paid by firms with stronger corporate governance structure (Armstrong et al., 2010; Hui \& Matsunaga, 2015). Moreover, this kind of firms are highly expected to design an incentive scheme based on non-financial measures (Ittner et al., 1997). It is highly probable that powerful boards realize the vitality of financial information and put their maximum time and effort on to receive great rewards. This is in line with the findings of Ajinkya et al. (2005) and Karamanou \& Vafeas (2005), who found that higher corporate governance leads to greater disclosure quality. In this regard, Ittner et al. (1997) declared that non-financial performance criteria are related to directors' power. Also, board characteristics is considered as the most determining factor in implementing reporting policies (Chen \& Jaggi, 2001; Chau \& Gray, 2010; Khlif \& Samaha, 2014). Estelyi \& Nisar (2016) consider a board as the core of a firm in decision making process and in pursuing different policies. They investigated the nationality of board members and its effects on firms' power and performance. The results demonstrated that national diversity of board members acts as the board strength and has a correlation with performance. Sariol \& Abebe (2017) examined the impacts of board power on firms' innovations and found a significantly positive relationship between the variables. Haque (2017) investigated the board characteristics and bonus plans and concluded that the gender of board members and their independence are not related with directors' incentives.

Based on the empirical findings reported above, previous studies have failed to consider the fact that the relationship between compensation and the quality of disclosed information could be moderated by some specific characteristics of board members including their educational condition, their independence, the presence of female members on board, or their duality. Accordingly, the present study aims to fill this gap in the literature.

\section{Duality on board}

In corporate governance literature, duality represents a board member who has the position of CEO simultaneously. Fama \& Jensen (1983) argue that the separation of control from ownership is an appropriate deterrent factor for conflict of interests and an improver of firm's values. In developing economies, duality has become increasingly popular in firms and family groups. The reason behind why firms are eager in duality is that they focus on leadership more. Gordon et al. (2005) indicate that duality may attenuate the board's independence and affects performance in a negative way. Also, duality may facilitate managerial entrenchment (Pfeffer, 1981), and may strengthen conflict of interests (Kim et al., 2008). Agency framework of Fama \& Jensen (1983) declares that the structural integrity of leadership decreases the importance of the separation between decision management (CEO) and decision control (chair of the board). Thus, duality alleviates monitoring and improves board compromise and balances (Cerbioni \& Parbonetti, 2007; Samaha et al., 2012; Khlif \& Samaha, 2014). On the other hand, a CEO 
has access to the most fundamental and private information and his duality may restrain the full transformation of information between CEO and board members and results in voluntary disclosure decreases (Kim et al., 2008). However, Anderson \& Anthony (1986), believe that duality causes the emergence of an outspoken and powerful leadership in a firm's strategic structure and leads to productivity consolidation. They argue that a unified leadership structure reduces the cost of sharing information, and also, lessens the conflict of interests between the $\mathrm{CEO}$ and the chairman. Supporters of duality are of the opinion that leadership clarity and unity of command palliate agency conflicts and improve decision making's process (Rhoades et al., 2001).

There have been many contradictory empirical evidence about the relationship between duality and voluntary disclosure. Li et al. (2008) reported a significant and negative relationship between the two-mentioned variables, while Cheng \& Courtenay (2006) and Haniffa \& Cooke (2002) found a positive relationship. Wang \& Dewhirst (1992) contend that boards' characteristics such as duality or the ratio of external directors may have an impact on shareholders diversity structure, and as a result, affect the way by which information are disclosed. Findings of Samaha et al. (2015) illustrate that in the relationship between board's size, bonus and duality with the information that are disclosed voluntarily, a country's location is a vital and determining factor. Lim et al. (2007) conclude that board's aspects have an impact on information disclosure in various ways. Because it is widely believed that audit committee and board members insist on protecting the shareholders' interests (Ayuso \& Argandoña, 2007), they always care about shareholders' benefits and focus on strategic financial information. On the other hand, a CEO who has a position on board may disclose less information. Furthermore, the proprietary costs theory argues that in short-term periods, directors tend to boost firm's performance and augment their bonuses by disclosing less environmental information about the firm. Taken together, we base our conjecture upon the previous arguments and present the first hypothesis as follows:

H1: There is a significant relationship between board compensation and disclosure quality in firms with duality on board.

\section{Education level \& degree}

Directors' role in firms' performance is a debatable subject amongst many researchers. On the one hand, organizational ecologists address the directors' importance for a firm. Their belief lies in the fact that a firm's success is based on the products quality, life cycle, firm's competency, and even luck; not the directors' skills or expertise (Cohen et al., 1972; Hannan $\&$ Freeman, 1977). On the other hand, the up upper echelon theory argues that directors are the ones who have an impact on a firm's performance (Hambrick \& Mason, 1984; Harris \& Helfat, 1997; Hayes \& Schaefer, 2000). The main purpose of the theory is to demonstrate that it is a firm's output which shows the knowledge and ability of the directors (Becker, 1962; Amit \& Shoemaker, 1993; Coff, 2002). Directors' experiences and background form the decisions they make (Hambrick and Mason, 1984; Hitt and Ireland, 1985). Prior researches declare that directors with operational background are able to identify and tackle relative issues in a more efficient way. Koyuncu et al. (2010), For instance, indicated that directors with operational background can handle production line issues in a more appropriate way. While, directors with business experiences can aid in marketing difficulties (Boyd et al., 2010). Managerial ability is the directors' substantial expertise in different industries by which they maximize 
firms' earnings and profitability (Krishnan \& Wang, 2015). Firms managed by financial experts experience development in both financial strategies (Custodio \& Metzger, 2014), and disclosure procedures (Matsunaga et al., 2013). Moreover, because financial experts enhance earnings quality, they pay lower audit fees as well (Kalelkar \& Khan, 2016). Directors' financial abilities can create value in various ways such as efficient use of cash resources and better investment decisions (Custodio \& Metzger, 2014). Because directors formulate final strategies about internal decisions, when they have financial expertise, they will have a far more fundamental role (Kalelkar \& Khan, 2016). Matsunaga et al. (2013) indicate that firms employing financial specialists report conservatively. They specifically illustrate that due to the high association between fiscal policies and financial managers, they are able to monitor the financial reporting quality in a more appropriate way.

Based on the corporate governance mechanism, board members are able to use their educational capabilities in order to provide services (Dalton \& Daily, 1999; Rindova, 1999; Westphal, 1999), depend on resources (Collins, 1971; Pfeffer, 1972; Hillman \& Dalziel, 2003), control (Fama \& Jensen, 1983), and monitor firms' current decisions (Johnson et al., 1996; Young et al., 2001). Board members' education level have an impact on business policies followed by the directors (Forbes \& Miliken, 1999; Rindova, 1999). Also, it enables them to provide services in terms of strategic consultations (Dalton \& Daily, 1999; Westphal, 1999). directors' education level and abilities can be considered as business services provided for firms (Rindova, 1999). Academic education and background of board members represent their participation in socio-economic areas and illustrate their capabilities in development and growth of external business activities (Collins, 1971; Pfeffer, 1972; Hillman \& Dalziel, 2003; Stevenson \& Radin, 2009). Nanda \& Onal (2016) came to a conclusion that various methods for paying bonus will be applied and less stock-based compensations are paid when there are expert managers in different industries, and also when they are aware of environmental issues of the industries. Of course, there have always been various criteria for gauging managers' education level from "unskilled worker" to "professor" (Almus, 2002), "college education" to "higher education" (Barringer et al., 2005), and "primary school" to "long higher education" (Senderovitz et al., 2016). According to preceding studies and discussions, we conjecture that educated members may increase profitability and have accurate profit forecast; they make better investment decisions, create value for their firm, and pay less audit fees to auditors. Thus, we formulate our second and third hypotheses as follows:

H2: Board members' education level has a significant impact on the relationship between board compensation and disclosure quality.

H3: Board members' education degree has a significant impact on the relationship between board compensation and disclosure quality.

\section{Female on board}

Firstly, because of the various and nontraditional views toward different issues, gender variety may have an impact on the decision making process (Adams et al., 2015). A diverse board illustrates the conception it has of the business environment (Miller \& Triana, 2009; Triana et al., 2013). It may also have a deeper understanding of the shareholders' range of interests (Harjoto et al., 2014). Furthermore, it can help firms by using individuals' skills such as prestige, financing, knowledge, legitimacy and diversity (Terjesen et al., 2009). Secondly, female managers are distinct from the peer males and have different priorities in mind (Adams 
\& Ferreira, 2009; Adams \& Funk, 2012). Female directors have different leadership styles (Bear et al., 2010), and support responsibility projects and social communities (Hillman et al., 2002). Presence of some females on board makes interaction mechanism with shareholders being supported and causes financial reports being validated (Manetti \& Toccafondi, 2012). Moreover, female directors are truly distinct in personality, education background, professional experience, and dialogue style (Liao et al., 2015). Female managers are more averse to loose legitimacy and reputation (Srinidhi et al., 2011). According to these differences, a diverse board may have an impact on the sustainability of financial reporting quality. Thirdly, women show eagerness toward making risk averse decisions, they focus on shareholders' interests more, and they are more accountable in behavioral and ethical issues (Carter et al., 2003; Adams \& Ferreira, 2009). It should be noted that the effects of gender may be derived from other board characteristics (Srinidhi et al., 2011). The Davies Report (2011), and the Higgs Report (2003) stated that a board and its members may have a wide range of backgrounds and viewpoints. Likewise, European Commission $(2012 ; 2014)$ declared that females have various goals and intentions. Their report about females' decisions demonstrated that the quality of ethical behavior in firms is affected by the ratio of females on board. Higgs Report (2003), discussed about the independent directors' roles and declared that gender diversity may boost their performance.

Based on the preceding discussions, we hypothesize that females, in comparison to men, have different priorities, style, prestige and a better understanding of their environment. Moreover, when a female member is on board, there is less tension during the meetings and financial reports are more validated. All in all, we expect that the presence of females on board may have a significant and positive impact on the relationship between board compensation and disclosure quality. This leads us to our fourth hypothesis as follows:

H4: There is a significant relationship between board compensation and disclosure quality in firms with females on board.

\section{Non-executive on board}

Agency theory suggests that non-executive directors may have an enormous effect on the efficaciousness of boards' monitoring procedures (Fama \& Jensen, 1983). Samaha et al. (2012) and Patelli \& Prencipe (2007) contend that by voluntary disclosure, external directors may achieve greater public reputation as expert supervisors in the market. Moreover, Meca \& Ballesta (2010) argue that non-executive directors are eager to put pressure on internal directors to improve financial disclosure policies via voluntary disclosure. On the other hand, Patelli \& Prencipe (2007) demonstrated that because external directors are chosen by the majority of shareholders, the monitoring role of minor shareholders is restricted (Demb \& Neubauer, 1992). In this situation, high proportion of external directors can have an impact on voluntary disclosure quality negatively. It is also argued that external managers are not completely independent and have deep interactions with major shareholders. These statements may be compatible with the boards and the audit committees' role in improving financial disclosure strategies. When directors are not truly independent, CEO acts in a more comfortable environment and takes the initiatives about financial reporting and related strategies (Barako et al., 2006). We are if the opinion that when independent directors are on board, more efficacious monitoring roles are implemented. We argue that independent managers put pressure on the executives to disclose 
voluntary information, and to improve their disclosure strategies; we believe that they actually care about seizing reputation by this. Moreover, participation of the non-executives may alleviate conflict of interests and more risky-innovative policies may be pursued. Altogether, we anticipate a significant positive relationship between board compensation and disclosure quality when there are independent directors on board:

H5: There is a significant relationship between board compensation and disclosure quality in firms with non-executives on boards.

\section{Export \& segment}

Based on the findings of Kalelkar \& Khan (2016), the number of a firm's subsidiaries along with its foreign activities are some of the most determining factors for evaluating the complexity of a firm performance. Ma et al. (2014) also argue that internationalization is a condition in which market research is conducted in the overseas, distribution channels are improved, foreign demands are adapted, export licenses from destination markets are acquired, and manufacturing facilities are set up. Bushman et al. (2016) and Sanders \& Carpenter (1998) indicate that the more a firm is internationalized, the higher complexities its directors are going to struggle with. Carpenter \& Sanders (2004) are of the opinion that the complexity which multi-national firms have inherited puts a huge burden on the directors' shoulders, it augments their responsibility, and requires higher exerted efforts. researches in the audit fees field shows that complexity is one of the key aspects of a firm's characteristics (Simunic \& Stein, 1996; Gul \& Tsui, 2001; Ferguson et al., 2003; Vafeas \& Waeglein, 2007; Hay et al., 2008). Moreover, complexity is related to the various firm activities. Rose \& Shepard (1997), came to a conclusion that when firms have more segments, they assign more tasks to the directors and heighten their bonus either. If the number of segments is grown, a director has to cope with more employees, and manage, analyse and evaluate the results and outcomes of their works (Balsam et al., 2012). According to the preceding discussions, we envisage that complex firms - which have foreign sales and control some subsidiaries - have to struggle in many different aspects including financial and operational issues. They also need to report their statements vividly and compensate their directors' exerted efforts to maximize the firms' outcomes if they want to survive in a cut-throat market. In this regard, we hypothesize that in firms which have export and subsidiaries, board compensation and disclosure quality have a significant and positive relationship:

H6: Export levels have a significant impact on the relationship between board compensation and disclosure quality.

H7: Segments have a significant impact on the relationship between board compensation and disclosure quality.

\section{Research design and sample selection procedure}

\section{Regression models}

To test our hypotheses, we employ two sets of regression models with disclosure quality as the independent variable and compensation as the dependent variable. We also include a relevant set of control variables along with some mediator variables. The initial model focuses on the financial information disclosure quality and turns it into a quantitative variable. We examine this model by employing the following equation: 
Disclosure Quality $_{i t}=\beta_{0}+\beta_{1}$ LnAsset $_{i t}+\beta_{2}$ Market-to-Book $_{i t}+\beta_{3}$ ROA $_{i t}+\beta_{4}$ InstitutionalOwn ${ }_{i t}+\beta_{5}$ Leverage $_{i t}+$ $\beta_{6}$ Loss $_{i t}+\beta_{7}$ ROAVolatility $_{i t}+\beta_{8}$ Earn $_{i t}+\beta_{9}$ ForeignSales $_{i t}+\beta_{10}$ InsiderOwn $_{i t}+\beta_{11}$ Segments $_{i t}+$ IndustryDummies + YearDummies $+\varepsilon_{i t} \quad(1)$

The residual term of model(1) is the measure of disclosure quality that will be used in the next equation. Our second regression model focuses on the relationship between compensation and disclosure quality. We employ the following equation to examine the mentioned relationship:

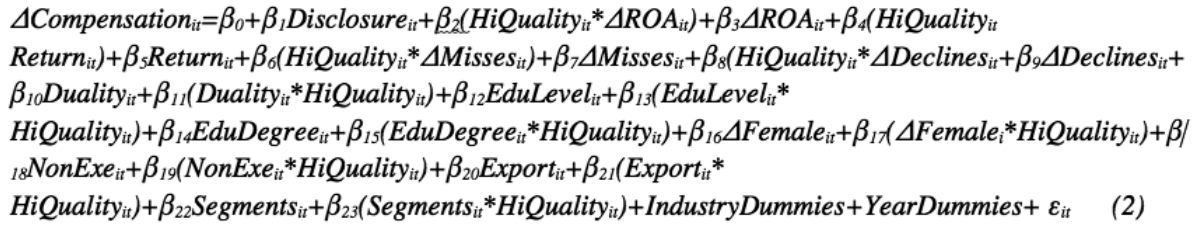

In model (2), $\Delta$ Compensation (board compensation) is our variable of interest and used as the dependent variable. Disclosure quality of financial information is our independent variable which is derived from the model (1). Regarding the moderator variables, we use a series of corporate governance variables including board members' education level (EduLevel); board members' education degree (EduDegree); if CEO has a position on Board (Duality); females on board (Female); independent directors on board (NonExe); foreign sales (Exports); and the number of subsidiaries (Segments). The information shown in table (1) is a succinct description of variables used in our models.

Table 1. Variable Definitions

\begin{tabular}{|c|c|}
\hline Variable & Measure \\
\hline Disclosure Quality & $\begin{array}{l}\text { Disclosure quality rankings of Iranian listed firms distributed by Tehran } \\
\text { Securities and Exchange Organization }\end{array}$ \\
\hline LnAsset & Natural log of total assets which represents firm size \\
\hline Market-to-Book & Market value of equity divided by the book value of equity \\
\hline ROA & Net income divided by total assets \\
\hline Institutional Ownership & $\begin{array}{l}\text { Total percentage of shares owned by governmental firms, banks, } \\
\text { investment firms, and insurance firms }\end{array}$ \\
\hline Leverage & Total liabilities divided by total assets \\
\hline Loss & Equal to one if the firm reported a loss and zero otherwise \\
\hline ROA-Volatility & $\begin{array}{l}\text { Standard deviation of the annual return on assets for the four-year period } \\
\text { prior to current year }\end{array}$ \\
\hline Earn & $\begin{array}{l}\text { (Earnings Sustainability) Derived from the model developed by Dichow } \\
\text { \& Dichev (2002) }\end{array}$ \\
\hline Insider Ownership & Total percentage of shares owned by board members \\
\hline Segments & $\begin{array}{l}\text { Total number of business segments that the mother firm owns at least } \\
50 \% \text { of their shares }\end{array}$ \\
\hline$\Delta$ Compensation & $\begin{array}{l}\text { (Bonus Growth) Measured by the natural log of total compensation of } \\
\text { year t minus the year } \mathrm{t}-1\end{array}$ \\
\hline
\end{tabular}


Disclosure

HiQuality

$\triangle \mathrm{ROA}$

Return

$\Delta$ Misses

$\Delta$ Declines

Duality

Education Level

Education Degree

Female

Non-Executives

Export
Residual term of the first model of disclosure quality; We utilized the data on disclosure scores disclosed publicly by the TSE on an annual or quarterly basis to calculate the financial disclosure quality of TSE listed companies. This score is calculated as the sum of reliability and timeliness scores of financial disclosure.

If the residual from the first regression model for year $\mathrm{t}$ is above the sample median, it takes the value of one, and zero otherwise

Return on assets for year $\mathrm{t}$ less return on assets for year $\mathrm{t}-1$

Annual stock return for year $\mathrm{t}$

Deviation between management forecast and realized earnings

Earnings-per-share for year $\mathrm{t}$ less the earnings-per-share for year $\mathrm{t}-1$

If CEO has a chair on board, it takes the value of one, and zero otherwise

Education level of board members which represent the highest value respectively: $1=\mathrm{Ph} . \mathrm{D} ., 2=$ master, $3=$ bachelor, and $4=$ associate

Education degree of board members which represent the highest value respectively: $1=$ finance, $2=$ =management, $3=$ =conomics, and $4=$ engineering

Total number of females on board

Total number of non-executive managers on board

Total export sales divided by total assets in year $\mathrm{t}$

\section{Sample selection procedure}

We obtain our required data manually from the hardcopy financial statements held in the TSE library (i.e. Codal1 and its supplementary software known as Rahavard Novin) for the sample 2010 to 2016. We then exclude firms with non-calendar fiscal year end, firms with missing or insufficient variable data and firms with fiscal year change during 2010-2016. We also exclude firms operating in banking industry as well as financial and investment institutions to measure the variables used in our equations, primarily because financial institutions and banking industry have different reporting requirements that could influence the figures associated with dependent variables. This leaves us with a primary sample of 1232 firm-year observations (see Table 2). The distribution of sample among industries is displayed in Table 2, indicating that the at top of the table are minerals \& mining and the automotive \& parts manufacturing industries with $23.86 \%$ and $17.05 \%$ of the whole sample observations, followed by the machinery \& equipment, chemical, pharmaceutical, food \& beverage, and metal industries with $14.2 \%$, $12.5 \%, 11.93 \%, 10.23 \%$ and $10.23 \%$ of the sample observations respectively.

Table 3 provides descriptive statistics of the variables used in the regression models. For Duality, the mean value of 0.8519 indicates that about $85 \%$ of the firms have a duality on board. Regarding Female, The mean and max values show that very few firms had females on board. The mean of EduLevel reveals that members who have Bachelor degree with 2.1282 are the most, followed by Master, Ph.D., and Associate with 1.7289, 0.8174, and 0.1485 respectively. Also, the mean value of EduDegree reveals that members who have Engineer degree with 1.3750 are the most, followed by Management, Finance, and Economy with 0.7565, 0.3458, and 0.0990 respectively. The mean value of NonExe is 0.6718 , demonstrating that majority of sample firms approximately had 3 non-executive directors on board. Also, the means of Export and Segments indicate that our sample firms have operational complexities. 
Table 2.Sample Distribution by Industry

\begin{tabular}{llll}
\hline Industry & Firms & Observations & \% \\
\hline Pharmaceutical & 21 & 147 & 11.93 \\
Machinery \& Equipment & 25 & 175 & 14.20 \\
Automotive \& Parts Manufacturing & 30 & 210 & 17.05 \\
Minerals \& Mining & 42 & 294 & 23.86 \\
Chemical & 22 & 154 & 12.50 \\
Food \& Beverage & 18 & 126 & 10.23 \\
Metal & 18 & 126 & 10.23 \\
Total & 176 & 1232 & 100 \\
\hline
\end{tabular}

Table 3.Descriptive Statistics

\begin{tabular}{lllllll}
\hline Variable & & Mean & Median & SD & Min & Max \\
\hline$\Delta$ Compensation & & 0.3391 & 0.0000 & 1.5894 & -1.0000 & 8.0064 \\
Disclosure & & 166.7970 & 65.2626 & 401.0160 & -214.7653 & 3291.4181 \\
$\Delta$ ROA & -0.0113 & -0.0094 & 0.1049 & -1.9433 & 0.5305 \\
Return & & 0.5465 & 0.2077 & 1.0643 & -0.6573 & 8.5950 \\
$\Delta$ Misses & & -76.0883 & -22.6575 & 1068.2767 & -7432.6000 & 23270.9881 \\
$\Delta$ Declines & & -31.9763 & -6.0420 & 1042.1779 & -6635.8600 & 13506.0000 \\
Duality & & 0.8519 & 1.0000 & 0.3553 & 0.0000 & 1.0000 \\
& Ph.D. & 0.8174 & 0.0000 & 1.1322 & 5.0000 & 0.0000 \\
EduLevel & Master & 1.7289 & 2.0000 & 1.3355 & 5.0000 & 0.0000 \\
& Bachelor & 2.1282 & 2.0000 & 1.4649 & 7.0000 & 0.0000 \\
& Associate & 0.1485 & 0.0000 & 0.4785 & 3.0000 & 0.0000 \\
& Finance & 0.3458 & 0.0000 & 0.6326 & 4.0000 & 0.0000 \\
EduDegree & Management & 0.7565 & 0.0000 & 1.1658 & 5.0000 & 0.0000 \\
& Economics & 0.0990 & 0.0000 & 0.3173 & 2.0000 & 0.0000 \\
Female & Engineering & 1.3750 & 1.0000 & 1.5675 & 5.0000 & 0.0000 \\
NonExe & & 0.0138 & 0.0000 & 0.0526 & 0.0000 & 0.6000 \\
Export & & 0.6718 & 0.6000 & 0.1969 & 0.0000 & 1.0000 \\
Segments & & 9.2109 & 9.5024 & 5.5137 & 0.0000 & 16.8204 \\
\hline
\end{tabular}

\section{Empirical results}

We employ panel data approach in our analyses and present the results across Table 4-10 using the EFA (exploratory factor analysis). In using the EFA, the independent variable "Disclosure" remains constant, and step-by-step, other independent-insignificant variables are eliminated from the test. We exclude the independent variable with the highest coefficient 
in each step, and then, the significance of the remaining variables is evaluated. Initially, we calculated the residual term of disclosure quality in model (1). For the sake of brevity, we exclude reporting the equation and its results and then we put it in the second equation along with the other variables. Table (4) presents the first test result, including the first hypothesis (H1) in three columns. It includes compensation and disclosure quality in firms with duality along with the control variables. Table (5) presents the second hypothesis $(\mathrm{H} 2)$ including moderating variable of EduLevel. As for the (H3), we examine the relationship between compensation and disclosure quality with the presence of EduDegree in Table (6). Table (7) indicates the fourth hypothesis (H4) including moderating variable of Female. We aim to examine if the participation of female members in board moderates the relationship between compensation and disclosure quality. Next comes Table (8) for our fifth hypothesis (H5). We include the moderating variable of NonExe here. Last but not the least, as for the sixth (H6) and seventh (H7) hypotheses, we consider Export and Segments to have a moderating role on the mentioned relationship.

Table (4) illustrates our first test results where we include duality on board (Duality) as the moderator variable. Unlike what we anticipated, we find that the coefficient on (Factor(H)1: Duality) is 0.5018 , and duality has no significant impact on the relationship between board compensation and disclosure quality, meaning that when the bonuses are going to be paid, the presence of CEO on board does not moderate the disclosure quality in Iranian family firms.

Table 4. Compensation and disclosure quality in the presence of duality

\begin{tabular}{llll}
\hline \multirow{2}{*}{ Variable } & H1 & & \\
\cline { 2 - 4 } (Intercept) & Coefficient & t-statistic & Sig. \\
Disclosure & $0.0000^{* * *}$ & 6.1060 & 1.1470 \\
$\Delta$ ROA & 0.9489 & -0.0640 & 0.0000 \\
Return & $0.0703^{*}$ & 1.8110 & 1.1260 \\
$\Delta$ Misses & $0.0018^{* * *}$ & 3.1220 & 0.2194 \\
$\Delta$ Declines & 0.9486 & -0.0640 & 0.0000 \\
Duality & $0.0896 *$ & 1.6990 & 0.0002 \\
Factor(ind)2 & 0.7744 & 0.2870 & 0.0398 \\
Factor(ind)3 & 0.2912 & -1.0560 & -0.1802 \\
Factor(ind)4 & 0.8972 & -0.1290 & -0.0214 \\
Factor(ind)5 & 0.7623 & 0.3030 & 0.0523 \\
Factor(ind)6 & 0.7634 & -0.3010 & -0.0524 \\
Factor(ind)7 & 0.1354 & -1.4940 & -0.2097 \\
Factor(year)2011 & 0.3146 & -1.0060 & -0.1576 \\
Factor(year)2012 & $0.0000 * * *$ & -5.5840 & -0.9081 \\
Factor(year)2013 & $0.0000^{* * *}$ & -5.8630 & -0.9602 \\
Factor(year)2014 & $0.0000^{* * *}$ & -6.1020 & -1.0070 \\
Factor(year)2015 & $0.0000^{* * *}$ & -5.5180 & -0.9709 \\
Factor(year)2016 & $0.0000^{* * *}$ & -5.6660 & -0.9374 \\
\hline
\end{tabular}




\begin{tabular}{llll}
\hline Factor $(\mathrm{H}) 1: \Delta$ ROA & $0.0287 * *$ & 2.1910 & 2.2650 \\
Factor $(\mathrm{H}) 1:$ Return & 0.1017 & -1.6380 & -0.1400 \\
Factor $(\mathrm{H}) 1: \Delta$ Misses & 0.7504 & -0.3180 & 0.0000 \\
Factor $(\mathrm{H}) 1: \Delta$ Declines & 0.1859 & -1.3240 & -0.0002 \\
Factor $(\mathrm{H}) 1:$ Duality & 0.5018 & 0.6720 & 0.0797 \\
\hline
\end{tabular}

*Significant at the 0.10 level.; **Significant at the 0.05 level.; ***Significant at the 0.01 level.

Table (5) demosntares our second test results where we include education level (EduLevel) as the moderator variable. In contrast to what we expected, we find that the coefficient on (Factor (H)1: EduLevel) is 0.9080 , and disclosure quality has no significant relationship with compensation in firms with members of high education level, meaning that the participation of these experts in boards is unlikely to affect the mentioned relationship.

Table 5. Compensation and disclosure quality in the presence of education level

\begin{tabular}{|c|c|c|c|}
\hline \multirow{2}{*}{ Variable } & \multicolumn{3}{|l|}{$\mathrm{H} 2$} \\
\hline & Coefficient & $t$-statistic & Sig. \\
\hline (Intercept) & $0.0000^{* * *}$ & 7.7510 & 1.2100 \\
\hline Disclosure & 0.8363 & 0.2070 & 0.0000 \\
\hline$\triangle \mathrm{ROA}$ & $0.0581^{*}$ & 1.8970 & 1.1700 \\
\hline Return & $0.0021 * * *$ & 3.0770 & 0.2076 \\
\hline$\Delta$ Misses & 0.9916 & -0.0110 & 0.0000 \\
\hline$\Delta$ Declines & $0.0844 *$ & 1.7270 & 0.0002 \\
\hline EduLevel & 0.6608 & -0.4390 & -0.0271 \\
\hline Factor(ind)2 & 0.2463 & -1.1600 & -0.1957 \\
\hline Factor(ind) 3 & 0.8951 & -0.1320 & -0.0219 \\
\hline Factor(ind) 4 & 0.7490 & 0.3200 & 0.0554 \\
\hline Factor(ind) 5 & 0.7779 & -0.2820 & -0.0490 \\
\hline Factor(ind) 6 & 0.1325 & -1.5060 & -0.2113 \\
\hline Factor(ind) 7 & 0.3012 & -1.0340 & -0.1615 \\
\hline Factor(year)2011 & $0.0000^{* * *}$ & -5.5890 & -0.9080 \\
\hline Factor(year)2012 & $0.0000^{* * *}$ & -5.8540 & -0.9555 \\
\hline Factor(year)2013 & $0.0000^{* * *}$ & -6.1090 & -1.0050 \\
\hline Factor(year)2014 & $0.0000 * * *$ & -5.5230 & -0.9693 \\
\hline Factor(year)2015 & $0.0000^{* * *}$ & -5.6760 & -0.9387 \\
\hline Factor(year)2016 & $0.0000^{* * *}$ & -6.3040 & -1.0390 \\
\hline Factor(H)1: $\triangle \mathrm{ROA}$ & $0.0299 * *$ & 2.1740 & 2.2260 \\
\hline Factor(H)1:Return & 0.1289 & -1.5190 & -0.1192 \\
\hline Factor $(\mathrm{H}) 1: \Delta$ Misses & 0.7027 & -0.3820 & 0.0000 \\
\hline Factor $(\mathrm{H}) 1: \Delta$ Declines & 0.1727 & -1.3640 & -0.0002 \\
\hline Factor(H)1: EduLevel & 0.9080 & 0.1160 & 0.0101 \\
\hline
\end{tabular}

*Significant at the 0.10 level.; **Significant at the 0.05 level.; ***Significant at the 0.01 level. 
Table 6 represents our third test results where we include education degree (EduDegree) as the moderator variable. Contrary to our primary expectations, we find that the coefficient on (Factor $(\mathrm{H}) 1$ : EduDegree) is 0.4629 , and disclosure quality has no significant relationship with compensation in firms with members of high education degree, meaning that the participation of these experts in boards is unlikely to have a significant impact on the mentioned relationship.

Table 6. Compensation and disclosure quality in the presence of education degree

\begin{tabular}{|c|c|c|c|}
\hline \multirow{2}{*}{ Variable } & \multicolumn{3}{|l|}{ H3 } \\
\hline & Coefficient & $t$-statistic & Sig. \\
\hline (Intercept) & $0.0000^{* * *}$ & (Intercept) & $0.0000 * * *$ \\
\hline Disclosure & 0.8090 & Disclosure & 0.8090 \\
\hline$\triangle \mathrm{ROA}$ & $0.0614 *$ & $\triangle \mathrm{ROA}$ & $0.0614 *$ \\
\hline Return & $0.0020^{* * *}$ & Return & $0.0020 * * *$ \\
\hline$\Delta$ Misses & 0.9823 & $\Delta$ Misses & 0.9823 \\
\hline$\Delta$ Declines & $0.0830^{*}$ & $\Delta$ Declines & $0.0830 *$ \\
\hline EduDegree & 0.6975 & EduDegree & 0.6975 \\
\hline Factor(ind)2 & 0.2611 & Factor(ind)2 & 0.2611 \\
\hline Factor(ind) 3 & 0.9135 & Factor(ind) 3 & 0.9135 \\
\hline Factor(ind) 4 & 0.7415 & Factor(ind) 4 & 0.7415 \\
\hline Factor(ind) 5 & 0.7701 & Factor(ind) 5 & 0.7701 \\
\hline Factor(ind) 6 & 0.1334 & Factor(ind) 6 & 0.1334 \\
\hline Factor(ind) 7 & 0.3151 & Factor(ind) 7 & 0.3151 \\
\hline Factor(year)2011 & $0.0000^{* * *}$ & Factor(year)2011 & $0.0000 * * *$ \\
\hline Factor(year)2012 & $0.0000^{* * *}$ & Factor(year)2012 & $0.0000^{* * *}$ \\
\hline Factor(year)2013 & $0.0000^{* * *}$ & Factor(year)2013 & $0.0000 * * *$ \\
\hline Factor(year)2014 & $0.0000^{* * *}$ & Factor(year)2014 & $0.0000 * * *$ \\
\hline Factor(year)2015 & $0.0000^{* * *}$ & Factor(year)2015 & $0.0000 * * *$ \\
\hline Factor(year)2016 & $0.0000^{* * *}$ & Factor(year)2016 & $0.0000 * * *$ \\
\hline Factor(H)1: $\triangle \mathrm{ROA}$ & $0.0327 * *$ & Factor(H)1: $\triangle \mathrm{ROA}$ & $0.0327 * *$ \\
\hline Factor(H)1:Return & 0.1235 & Factor(H)1:Return & 0.1235 \\
\hline Factor $(\mathrm{H}) 1: \Delta$ Misses & 0.7174 & Factor $(\mathrm{H}) 1: \Delta$ Misses & 0.7174 \\
\hline Factor $(\mathrm{H}) 1: \Delta$ Declines & 0.1766 & Factor $(\mathrm{H}) 1: \Delta$ Declines & 0.1766 \\
\hline Factor $(\mathrm{H}) 1$ : EduDegree & 0.4629 & Factor $(\mathrm{H}) 1$ : EduDegree & 0.4629 \\
\hline
\end{tabular}

*Significant at the 0.10 level.; **Significant at the 0.05 level.; ***Significant at the 0.01 level. 
Table 7 presents our fourth test results where we include the presence of females on board (Female) as the moderator variable. In contrast to what we primarily expected, we find that the coefficient on (Factor $(\mathrm{H}) 1$ : Female) is 0.1357 , and disclosure quality has no significant relationship with compensation in firms which employed female members on board, meaning that when the bonuses are going to be paid, Iranian firms which have female members on board do not consider the quality of financial information reported by the directors.

Table 7. Compensation and disclosure quality in the presence of female

\begin{tabular}{|c|c|c|c|}
\hline \multirow{2}{*}{ Variable } & \multicolumn{3}{|l|}{ H4 } \\
\hline & Coefficient & $t$-statistic & Sig. \\
\hline (Intercept) & $0.0000 * * *$ & 7.7280 & 1.2080 \\
\hline Disclosure & 0.9932 & 0.0090 & 0.0000 \\
\hline$\triangle \mathrm{ROA}$ & $0.0642 * *$ & 1.8530 & 1.1420 \\
\hline Return & $0.0016^{* * *}$ & 3.1570 & 0.2131 \\
\hline$\Delta$ Misses & 0.9748 & -0.0320 & 0.0000 \\
\hline$\Delta$ Declines & $0.0870 *$ & 1.7130 & 0.0002 \\
\hline Female & 0.3848 & -0.8690 & -0.9760 \\
\hline Factor(ind) 2 & 0.2432 & -1.1680 & -0.1969 \\
\hline Factor(ind) 3 & 0.8866 & -0.1430 & -0.0236 \\
\hline Factor(ind) 4 & 0.7668 & 0.2970 & 0.0512 \\
\hline Factor(ind) 5 & 0.7722 & -0.2900 & -0.0502 \\
\hline Factor(ind) 6 & 0.1236 & -1.5410 & -0.2155 \\
\hline Factor(ind) 7 & 0.3126 & -1.0100 & -0.1577 \\
\hline Factor(year)2011 & $0.0000 * * *$ & -5.5780 & -0.9055 \\
\hline Factor(year)2012 & $0.0000 * * *$ & -5.8620 & -0.9568 \\
\hline Factor(year)2013 & $0.0000 * * *$ & -6.0370 & -0.9938 \\
\hline Factor(year)2014 & $0.0000 * * *$ & -5.5260 & -0.9688 \\
\hline Factor(year)2015 & $0.0000 * * *$ & -5.6450 & -0.9323 \\
\hline Factor(year)2016 & $0.0000 * * *$ & -6.3110 & -1.0390 \\
\hline Factor(H)1: $\triangle \mathrm{ROA}$ & $0.0316^{* *}$ & 2.1520 & 2.2030 \\
\hline Factor(H)1:Return & 0.1057 & -1.6190 & -0.1272 \\
\hline Factor(H)1: $\Delta$ Misses & 0.7215 & -0.3560 & 0.0000 \\
\hline Factor $(\mathrm{H}) 1: \Delta$ Declines & 0.1812 & -1.3380 & -0.0002 \\
\hline Factor(H)1: Female & 0.1357 & 1.4930 & 2.4240 \\
\hline
\end{tabular}

*Significant at the 0.10 level.; **Significant at the 0.05 level.; ***Significant at the 0.01 level. 
Table 8 indicates our fifth test results where we include the presence of independent directors on board (NonExe) as the moderator variable. Unlike what we expected, we find that the coefficient on $(F a c t o r(H) 1$ : NonExe) is 0.1057 , and compensation has no significant relationship with disclosure quality in firms which have independent members on board, meaning that when the bonuses are going to be paid, Iranian firms which have non-executives do not consider the quality of financial information reported by the managers.

Table 8. Compensation and disclosure quality in the presence of independent directors

\begin{tabular}{|c|c|c|c|}
\hline \multirow{2}{*}{ Variable } & \multicolumn{3}{|l|}{ H5 } \\
\hline & Coefficient & $t$-statistic & Sig. \\
\hline (Intercept) & $0.0000 * * *$ & 6.0380 & 1.3230 \\
\hline Disclosure & 0.6334 & -0.4770 & -0.0001 \\
\hline$\triangle \mathrm{ROA}$ & $0.0734 *$ & 1.7920 & 1.1090 \\
\hline Return & $0.0007 * * *$ & 3.4060 & 0.2385 \\
\hline$\Delta$ Misses & 0.8926 & -0.1350 & 0.0000 \\
\hline$\Delta$ Declines & $0.0978 *$ & 1.6570 & 0.0001 \\
\hline NonExe & 0.2367 & -1.1840 & -0.2743 \\
\hline Factor(ind)2 & 0.3441 & -0.9470 & -0.1608 \\
\hline Factor(ind) 3 & 0.9083 & -0.1150 & -0.0191 \\
\hline Factor(ind)4 & 0.7505 & 0.3180 & 0.0549 \\
\hline Factor(ind) 5 & 0.8208 & -0.2270 & -0.0394 \\
\hline Factor(ind) 6 & 0.1246 & -1.5370 & -0.2149 \\
\hline Factor(ind) 7 & 0.3197 & -0.9960 & -0.1554 \\
\hline Factor(year)2011 & $0.0000 * * *$ & -5.6290 & -0.9136 \\
\hline Factor(year)2012 & $0.0000^{* * *}$ & -5.9360 & -0.9686 \\
\hline Factor(year)2013 & $0.0000^{* * *}$ & -6.1930 & -1.0190 \\
\hline Factor(year)2014 & $0.0000 * * *$ & -5.6320 & -0.9894 \\
\hline Factor(year)2015 & $0.0000 * * *$ & -5.6930 & -0.9397 \\
\hline Factor(year)2016 & $0.0000 * * *$ & -6.3390 & -1.0430 \\
\hline Factor(H)1: $\triangle \mathrm{ROA}$ & $0.0199 * *$ & 2.3310 & 2.4170 \\
\hline Factor(H)1:Return & $0.0424 * *$ & -2.0320 & -0.1737 \\
\hline Factor(H)1: $\Delta$ Misses & 0.8131 & -0.2360 & 0.0000 \\
\hline Factor(H)1: $\Delta$ Declines & 0.1949 & -1.2970 & -0.0001 \\
\hline Factor $(\mathrm{H}) 1$ : NonExe & 0.1057 & 1.6190 & 0.2589 \\
\hline
\end{tabular}

*Significant at the 0.10 level.; **Significant at the 0.05 level.; ***Significant at the 0.01 level.

Table 9 demonstrates our sixth test results where we include foreign sales (Export) as the moderator variable. Unlike what we anticipated, we find that at $5 \%$ margin of error, the coefficient on (Factor (H)1: Export) is 0.0846 , and compensation has no significant relationship with disclosure quality in firms which have complex activities and export their products. But 
at $10 \%$ margin of error, the variable is positive and significant, meaning that when the bonuses are going to be paid, Iranian complex firms which have a number of exported goods on their financial statements consider the quality of financial information reported by the directors.

Table 9. Compensation and disclosure quality in the presence of export

\begin{tabular}{|c|c|c|c|}
\hline \multirow{2}{*}{ Variable } & \multicolumn{3}{|l|}{ H6 } \\
\hline & Coefficient & $t$-statistic & Sig. \\
\hline (Intercept) & $0.0000^{* * *}$ & 7.3620 & 1.2260 \\
\hline Disclosure & 0.7540 & -0.3130 & 0.0000 \\
\hline$\triangle \mathrm{ROA}$ & $0.0764 *$ & 1.7730 & 1.0950 \\
\hline Return & $0.0007 * * *$ & 3.3990 & 0.2352 \\
\hline$\Delta$ Misses & 0.9524 & -0.0600 & 0.0000 \\
\hline$\Delta$ Declines & $0.0958 *$ & 1.6670 & 0.0001 \\
\hline Export & 0.2763 & -1.0890 & -0.0105 \\
\hline Factor(ind)2 & 0.3367 & -0.9610 & -0.1630 \\
\hline Factor(ind) 3 & 0.9187 & -0.1020 & -0.0169 \\
\hline Factor(ind) 4 & 0.7125 & 0.3690 & 0.0637 \\
\hline Factor(ind) 5 & 0.8557 & -0.1820 & -0.0316 \\
\hline Factor(ind) 6 & 0.1310 & -1.5110 & -0.2113 \\
\hline Factor(ind)7 & 0.3296 & -0.9750 & -0.1523 \\
\hline Factor(year)2011 & $0.0000 * * *$ & -5.6750 & -0.9220 \\
\hline Factor(year)2012 & $0.0000 * * *$ & -5.9070 & -0.9633 \\
\hline Factor(year)2013 & $0.0000 * * *$ & -6.1700 & -1.0150 \\
\hline Factor(year)2014 & $0.0000^{* * *}$ & -5.5940 & -0.9815 \\
\hline Factor(year)2015 & $0.0000^{* * *}$ & -5.7090 & -0.9426 \\
\hline Factor(year)2016 & $0.0000^{* * *}$ & -6.3680 & -1.0480 \\
\hline Factor(H)1: $\Delta$ ROA & $0.0210 * *$ & 2.3120 & 2.3720 \\
\hline Factor(H)1:Return & $0.0459 * *$ & -1.9980 & -0.1655 \\
\hline Factor(H)1: $\Delta$ Misses & 0.7413 & -0.3300 & 0.0000 \\
\hline Factor $(\mathrm{H}) 1: \Delta$ Declines & 0.1889 & -1.3150 & -0.0002 \\
\hline Factor(H)1: Export & $0.0846 *$ & 1.7260 & 0.0192 \\
\hline
\end{tabular}

*Significant at the 0.10 level.; **Significant at the 0.05 level.; ***Significant at the 0.01 level.

Table 10 indicates our last test results where we include subsidiaries (Segments) as the moderator variable. In contrast to what we expected, we find that the coefficient on (Factor $(\mathrm{H}) 1$ : Segments) is 0.1755 , and disclosure quality has no significant relationship with compensation in firms which have complex activities and control a few subsidiaries, meaning that when the bonuses are going to be paid, Iranian complex firms which have a few number of segments do not consider the quality of financial information reported by the managers. 
Table 10. Compensation and disclosure quality in the presence of segments

\begin{tabular}{|c|c|c|c|}
\hline \multirow{2}{*}{ Variable } & \multicolumn{3}{|l|}{$H 7$} \\
\hline & Coefficient & $t$-statistic & Sig. \\
\hline (Intercept) & $0.0000^{* * *}$ & 7.8750 & 1.2430 \\
\hline Disclosure & 0.9986 & -0.0020 & 0.0000 \\
\hline$\triangle \mathrm{ROA}$ & $0.0686^{*}$ & 1.8230 & 1.1250 \\
\hline Return & $0.0015^{* * *}$ & 3.1900 & 0.2165 \\
\hline$\Delta$ Misses & 0.9320 & 0.0850 & 0.0000 \\
\hline$\Delta$ Declines & $0.0690 *$ & 1.8200 & 0.0002 \\
\hline Segments & 0.1162 & -1.5720 & -0.0234 \\
\hline Factor(ind)2 & 0.2692 & -1.1050 & -0.1866 \\
\hline Factor(ind) 3 & 0.8934 & -0.1340 & -0.0222 \\
\hline Factor(ind) 4 & 0.7954 & 0.2590 & 0.0448 \\
\hline Factor(ind) 5 & 0.8310 & -0.2130 & -0.0371 \\
\hline Factor(ind) 6 & 0.1152 & -1.5760 & -0.2208 \\
\hline Factor(ind) 7 & 0.2889 & -1.0610 & -0.1661 \\
\hline Factor(year)2011 & $0.0000 * * *$ & -5.6640 & -0.9213 \\
\hline Factor(year)2012 & $0.0000 * * *$ & -5.9340 & -0.9707 \\
\hline Factor(year)2013 & $0.0000^{* * *}$ & -6.1250 & -1.0110 \\
\hline Factor(year)2014 & $0.0000^{* * *}$ & -5.5700 & -0.9784 \\
\hline Factor(year)2015 & $0.0000^{* * *}$ & -5.6960 & -0.9415 \\
\hline Factor(year)2016 & $0.0000 * * *$ & -6.3640 & -1.0490 \\
\hline Factor(H)1: $\triangle \mathrm{ROA}$ & $0.0249 * *$ & 2.2460 & 2.3050 \\
\hline Factor(H)1:Return & $0.0900 *$ & -1.6970 & -0.1346 \\
\hline Factor $(\mathrm{H}) 1: \Delta$ Misses & 0.6498 & -0.4540 & -0.0001 \\
\hline Factor $(\mathrm{H}) 1: \Delta$ Declines & 0.1519 & -1.4340 & -0.0002 \\
\hline Factor $(\mathrm{H}) 1$ : Segments & 0.1755 & 1.3560 & 0.0260 \\
\hline
\end{tabular}

*Significant at the 0.10 level.; $* *$ Significant at the 0.05 level.; ***Significant at the 0.01 level.

\section{Conclusions}

There has been a large body of literature on the impact of disclosure quality on earnings management, earnings quality, firm's performance, etc. However, we aimed to examine the relationship between disclosure quality and board compensation when corporate governance elements are interfered, and the lack of empirical evidence in this regard has restricted our comprehension toward the paid compensation based on disclosure quality, particularly when corporate governance moderators are involved. We have attempted to extensively develop this subject. We focused on disclosure quality of Iranian listed firms' financial information, because the reported data is a determining criterion by which many investors trade shares, and especially, directors compensations are paid based on them; not only in Iran, but also 
in most developing countries. In this regard, we considered some of the most important and fundamental corporate governance factors along with two measures of firms' complexities. We truly believe that considering the unique financial situation and economic issues prevailing in the Middle East in the last couple of years, Iran would be a desirable sample for the study as a major developing country.

We carry out our empirical analyses by regressing disclosure quality on compensation when some important corporate governance factors are interfered. The findings indicate that disclosure quality is not associated with compensation when most of the mentioned factors are moderated, supporting the conjecture that when the bonuses are going to be paid, the presence of CEO on board does not heighten the disclosure quality in Iranian listed firms; the participation of educated board members, females, and independent members do not have any impact on the relationship. One of the most significant reasons behind this fact is that in contrast to what is applied in developed countries that disclosure quality improvement is the priority, some other criterion are priorities in developing countries like Iran. One leading cause of this issue could be the legislations enacted to disclose information. Along with this problem, another significant reason in comparison to the other international markets worldwide could be the emerging non-transparent capital market of Iran. In the Iranian stock market, connections and access to confidential data act as a key element toward the success in making tactical decisions. Moreover, we examined the relationship between disclosure quality and board compensation in complex firms. In this regard, we argue that foreign sales and subsidiaries may be reward-enhancing when high quality information is disclosed. We believe that the reason behind this is that these kind of firms are struggling in a cut-throat market and provide high quality information for the users. But this is not the fact for Iranian listed firms and even the international ones that tend to neglect this vital issue to compensate their directors' attempts. As for the moderator variable of segments, we found that when the bonuses are going to be paid, Iranian complex firms which have a few number of segments do not consider the quality of financial information reported by the managers. Finally, we considered whether complex firms which have foreign sales report information with higher quality and pay higher bonuses to their managers, but the results demonstrated the opposite results as there was no significant relationship between the variables. Nevertheless, at ten percent margin of error, the relationship was significant and positive, meaning that when the bonuses are going to be paid, Iranian complex firms which have a number of exported goods on their financial statements consider the quality of financial information reported by the directors.

\section{References}

Abdelsalam, O.H. \& Street, D.L. (2007). Corporate Governance and the Timeliness of Corporate Internet Reporting By U.K. Listed Companies. Journal of International Accounting, Auditing and Taxation, 16(2), 111-130. https:// doi.org/10.1016/j.intaccaudtax.2007.06.001

Aboody, D., \& Kasznik, R. (2000). CEO Stock Option Awards and the Timing of Corporate Voluntary Disclosures. Journal of Accounting and Economics, 29(1), 73-100.https://doi.org/10.1016/s0165-4101(00)00014-8

Adams, M., \& Hossain, M. (1998) Managerial Discretion and Voluntary Disclosure: Empirical Evidence from the New Zealand Life Insurance Industry. Journal of Accounting and Public Policy, 17(3), 245-281.https://doi.org/10.1016/ s0278-4254(98)10003-0

Adams, R. (2015). Myths and Facts about Female Directors. International Finance Corporation, Washington. Available at SSRN: https://ssrn.com/abstract=2603108 
Adams, R., \& Ferreira, D. (2009). Women in the Boardroom and Their Impact on Governance and Performance. Journal of Financial Economics, 94(2), 291-309.https://doi.org/10.1016/j.jfineco.2008.10.007

Adams, R., \& Funk, P. (2012). Beyond the Glass Ceiling: Does Gender Matter? Management Science, 58(2), 219-235.https:// doi.org/10.1287/mnsc.1110.1452

Adams, R., De Haan, J., Terjesen, S., \& Van Ees, H. (2015). Board Diversity: Moving the Field Forward. Corporate Governance: An International Review, 23(2), 77-82. https://doi.org/10.1111/corg.12106

Ajinkya, B., Bhojraj, S., \& Sengupta, P. (2005). The Association Between Outside Directors, Institutional Investors and the Properties of Management Earnings Forecasts. Journal of Accounting Research, 43(3), 343-376.https://doi.org/10.1111/ j.1475-679x.2005.00174.x

Almus, M. (2002). What Characterizes a Fast-Growing Firm? Applied Economics, 34(12), 1497-1508. https://doi. org/10.1080/00036840110105010

Amit, R., \& Shoemaker P. (1993). Strategic Assets and Organizational Rent. Strategic Management Journal, 14(1), 33-46. https://doi.org/10.1002/smj.4250140105

Anderson, C.A., \& Anthony, R.N. (1986). The New Corporate Directors: Insights for Board Members and Executives (New York: Whiley).

Anderson, R.C., Duru, A., \& Reeb, D.M. (2009). Founders, Heirs, and Corporate Opacity in the United States. Journal of Financial Economics, 92(2), 205-222. https://doi.org/10.1016/j.jfineco.2008.04.006

Armstrong, C.S., Guay, W.R., \& Weber, J.P. (2010). The Role of Information and Financial Reporting in Corporate Governance and Debt Contracting. Journal of Accounting and Economics. 50(2-3), 179-234. https://doi.org/10.1016/j. jacceco.2010.10.001

Ayuso, S., \& Argandoña, A. (2007). Responsible Corporate Governance: Towards a Stakeholder Board of Directors? (IESE Business School Working Paper No. 701). Retrieved December 10, 2013, Available at: https://doi.org/10.2139/ ssrn. 1349090

Ball, R., Kothari, S.P., \& Robin, A. (2000). The Effect of International Institutional Factors on Properties of Accounting Earning. Journal of Accounting and Economics; 29(1), 1-51. https://doi.org/10.1016/s0165-4101(00)00012-4

Balsam, S., Irani, A.J., \& Yin, Q.J. (2012). Impact of Job Complexity and Performance on CFO Compensation. Accounting Horizons, 26(3), 359-416. https://doi.org/10.2308/acch-50184

Banker, R., \& Datar, S. (1989). Sensitivity, Precision, and Linear Aggregation of Signals for Performance Evaluation. Journal of Accounting Research, 27(1), 21-39. https://doi.org/10.2307/2491205

Barako, D.G., Hancock, P., \& Izan, H.Y. (2006). Factors Influencing Voluntary Corporate Disclosure by Kenyan Companies. Corporate Governance: An International Review, 14(2), 107-125. https://doi.org/10.1111/j.1467-8683.2006.00491.x

Barnea, A., Haugen, R.Q., \& Senbet, L.W. (1985). Agency Problems and Financing Contracting, Englewood Cliffs Prentice-Hall.

Barringer, B.R., Jones, F.F., \& Neubaum, D.O. (2005). A Quantitative Content Analysis of the Characteristics of Rapid Growth Firms and Their Founders. Journal of Business Venturing, 20(5), 663-687. https://doi.org/10.1016/j.jbusvent.2004.03.004

Barth, M.E., \& Schipper, K. (2008). Financial Reporting Transparency. Journal of Accounting, Auditing \& Finance, 23(2), 173-190. https://doi.org/10.1177/0148558X0802300203

Barth, M.E., Konchitchki, Y., \& Landsman, W.R. (2013). Cost of Capital and Earnings Transparency. Journal of Accounting and Economics, 55(2-3), 206-224. https://doi.org/10.1016/j.jacceco.2013.01.004

Bazrafshan, E., Kandelousi, A.S., \& Hooy, C.W. (2015). The Impact of Earnings Management on the Extent of Disclosure and True Financial Performance: Evidence from Listed Firms in Hong Kong. The British Accounting Review, 48(2), $206-219$. https://doi.org/10.1016/j.bar.2015.09.001

Bear, S., Rahman, N., \& Post, C. (2010). The Impact of Board Diversity and Gender Composition on Corporate Social Responsibility and Firm Reputation. Journal of Business Ethics, 97(2), 207-221. https://doi.org/10.1007/s10551-010-0505-2

Becker, G.S. (1962). Investment in Human Capital: A Theoretical Analysis. Journal of Political Economy, 70(5), 9-49. https:// doi.org/10.1086/258724

Behrouzi, A., Banimahd, B., Soleymani, A. (2013). Audit Fees and Timeliness of Accounting Information: Evidence from Iran. Journal of Basic and Applied Scientific Research, 3(6), 481-487. Available in: https://www.textroad.com/pdf/JBASR/J.\%20Basic.\%20Appl.\%20Sci.\%20Res.,\%203(6)481-487,\%202013.pdf. 
Biddle, G.C., \& Hilary, G. (2006). Accounting Quality and Firm-Level Capital Investment. The Accounting Review, 81(5), 963-982. https://doi.org/10.2308/accr.2006.81.5.963

Biedleman, C. (1973). Income Smoothing: The Role of Management. The Accounting Review, 48(4), 653-667. Available in: https://www.jstor.org/stable/245289?seq=1\#page_scan_tab_contents.

Billings, M., \& Capie, F.H. (2009). Transparency and Financial Reporting in Mid-20th Century British Banking. Accounting Forum, 33(1), 38-53. https://doi.org/10.1016/j.accfor.2008.07.003

Bloomfield, R.J., \& Wilks, T.J. (2000). Disclosure Effects in the Laboratory: Liquidity, Depth, and the Cost of Capital. The Accounting Review, 75(1), 13- 42. https://doi.org/10.2308/accr.2000.75.1.13

Boo, E., Ng, T.B., \& Shankar, P.G. (2016). Effects of Incentive Scheme and Working Relationship on Whistle-Blowing in an Audit Setting. Auditing: A Journal of Practice \& Theory, 35(4), 23-38. https://doi.org/10.2308/ajpt-51485

Botoson, C.A. (1997). Disclosure Level and the Cost of Equity Capital. The Accounting Review, 72(3), 323-349. Available in: https://www.jstor.org/stable/248475?seq=1\#page_scan_tab_contents.

Bouckova, M. (2015). Management Accounting and Agency Theory. Procedia Economics and Finance, (25), 5-13.https:// doi.org/10.1016/s2212-5671(15)00707-8

Boyd D.E., Chandy, R., \& Cunha, M. (2010). When Do Chief Marketing Officers Impact Value? A Customer Power Explanation. Journal of Marketing Research, 47(6), 1162-1176.https://doi.org/10.1509/jmkr.47.6.1162

Bratten, B., \& Xue, Y. (2016). Institutional Ownership and CEO Equity Incentives. Journal of Management Accounting Research, Online-Early, Available at: https://doi.org/10.2308/jmar-51599

Brown, J.O., \& Popova, V.K. (2016). The Interplay of Management Incentives and Audit Committee Communication on Auditor Judgment. Behavioral Research in Accounting, 28(1), 27-40.https://doi.org/10.2308/bria-51259

Bushee, B.J. \& Noe, C.F. (2000). Corporate Disclosure Practices, Institutional Investors, and Stock Return Volatility. Journal of Accounting Research, 38, 171-202. https://doi.org/10.2307/2672914

Bushman, R.M., \& Indjejikian, R.J. (1993). Accounting Income, Stock Price, and Managerial Compensation. Journal of Accounting \& Economics, 16(1-3), 3-23. https://doi.org/10.1016/0165-4101(93)90003-x

Bushman, R.M., \& Smith, A.J. (2001). Financial Accounting Information and Corporate Governance. Journal of Accounting and Economics, 32(1-3): 237-333.https://doi.org/10.1057/9781137435613.0014

Bushman, R.M., \& Smith, A.J. (2003). Transparency, Financial Accounting Information, and Corporate Governance. FRBNY Economic Policy Review, 9(1), 65-87. Available at SSRN: https://ssrn.com/abstract=795547

Bushman, R.M., Dai, Z., \& Zhang, W. (2016). Management Team Incentive: Dispersion and Firm Performance. The Accounting Review, 91(1), 21-45. https://doi.org/10.2308/accr-51112

Bushman, R.M., Pitotroski, J., \& Smith, A. (2004). What Determines Corporate Transparency? Journal of Accounting Research.42(2), 207-252. https://doi.org/10.2139/ssrn.428601

Cadman, B., \& Sunder, J. (2014). Investor Horizon and CEO Horizon Incentives. The Accounting Review, 89(4), 1299-1328. https://doi.org/10.2308/accr-50719

Carpenter, M., \& Sanders, W.M. (2004). The Effects of Top Management Team Pay and Firm Internationalization on MNC Performance. Journal of Management, 30(4), 509-528. https://doi.org/10.1016/j.jm.2004.02.001

Carter, D.A., Simkins, B., \& Simpson, W.G. (2003). Corporate Governance, Board Diversity, and Firm Value. The Financial Review, 38(1), 33-53. https://doi.org/10.1111/1540-6288.00034

Cerbioni, F., \& Parbonetti, A. (2007). Exploring the Effects of Corporate Governance on Intellectual Capital Disclosure: An Analysis of European Biotechnology Companies. European Accounting Review. 16 (4), 791-826. https://doi. org/10.1080/09638180701707011

Chang, S.J., \& Hong, J. (2000). Economic Performance of Group-Affiliated Companies in Korea: Intragroup Resource Sharing and Internal Business Transaction. Academy of Management Journal, 43(3), 421-448. https://doi.org/10.5465/1556403

Chang, Y.Y., Dasgupta, S., \& Hilary, G. (2010). CEO Ability, Pay, and Firm Performance. Management Science, 56(10), 16331652. https://doi.org/10.1287/mnsc.1100.1205

Chau, G., \& Gray, S.J., (2010). Family ownership, Board Independence and Voluntary Disclosure: Evidence from Hong Kong. Journal of International Accounting Auditing and Taxation, 19(2), 93-109. https://doi.org/10.1016/j.intaccaudtax.2010.07.002

Chen, C., \& Jaggi, B. (2001). Association between Independent Non-Executive Directors, Family Control and Financial Disclosures in Hong Kong. Journal of Accounting and Public Policy, 19(4), 285-31. https://doi.org/10.1016/s02784254(00)00015-6 
Chen, Q., Dikolli, S.S, \& Jiang, W. (2015). Career-Risk Concerns, Information Effort, and Optimal Pay-for-Performance Sensitivity. Journal of Management Accounting Research, 27(2), 165-195. https://doi.org/10.2308/jmar-51165

Cheng, E.C.M., \& Courtenay, S.M. (2006). Board Composition, Regulatory Regime and Voluntary Disclosure. The International Journal of Accounting, 41(3), 262-289. https://doi.org/10.1016/j.intacc.2006.07.001

Choi, J.W. (2014). Can Offering a Signing Bonus Motivate Effort? Experimental Evidence of the Moderating Effects of Labor Market Competition. The Accounting Review, 89(2), 545-570. https://doi.org/10.2308/accr-50641

Coff, R.W. (2002). Human capital, shared expertise, and the likelihood of Impasse in Corporate Acquisitions. Journal of Management, 28(1), 107-128. https://doi.org/10.1016/s0149-2063(01)00127-1

Cohen, M.D., March, J.G., \& Olsen, J. P. (1972). A Garbage Can Model of Organizational Choice. Administrative Science Quarterly, 17(1), 1-25. https://doi.org/10.2307/2392088

Collins, R. (1971). Functional and Conflict Theories of Educational Stratification. American Sociologic Review, 36(6), 10021019. https://doi.org/10.2307/2093761

Core, J., \& Guay, W. (1999). The Use of Equity Grants to Manage Optimal Equity Incentive Levels. Journal of Accounting and Economics, 28(2), 151-184. https://doi.org/10.1016/s0165-4101(99)00019-1

Custodio, C., \& Metzger, D. (2014). Financial Expert CEOs: CEO’s Work Experience and Firm's Financial Policies. Journal of Financial Economics, 114(1), 125-154. https://doi.org/10.1016/j.jfineco.2014.06.002

Dalton, D. R., \& Daily, C. M. (1999). What's Wrong With Having Friends on the Board? Across the Board, 36(3), 2832. Available in: https://elibrary.ru/item.asp?id=3466781

Davies Report, (2011). Women on Boards: An Independent Review into Women on Boards. Department for Business Innovation and Skills (BIS), London. Technical Report. Available in: https://www.gov.uk/government/news/women-on-boards.

Dechow, P.M., \& Dichev, L.D. (2002). The Quality of Accruals and Earnings: The Role of Accrual Estimation Errors. The Accounting Review, 77.35-59.https://doi.org/10.2308/accr.2002.77.s-1.35

Demb, A., \& Neubauer, F.F. (1992). The Corporate Board. Oxford University Press, Oxford. Available in: https://www. researchgate.net/profile/Ada_Demb/publication/13178296_The_corporate_board_Confronting_the_paradoxes/ links/5a0606394585157013a39808/The-corporate-board-Confronting-the-paradoxes.pdf

Diamond, D.W., \& Verrocchia, R.E. (1991). Disclosure, Liquidity, and the Cost Capital. The Journal of Finance, 46(4), 13251360. https://doi.org/10.2307/2328861

Duong, L., \& Evans, J. (2015). CFO Compensation: Evidence from Australia. Pacific-Basin Finance Journal, 35(1), 425-443. https://doi.org/10.1016/j.pacfin.2015.03.006

Easley, D., \& O'Hara, M. (2004). Information and the Cost of Capital. The Journal of Finance, 59(4), 1553-1583. https://doi.org/10.1111/j.1540-6261.2004.00672.x

Eng, L. \& Mak, Y. (2003). Corporate Governance and Voluntary Disclosure. Journal of Accounting and Public Policy, 22(4), 325-345. https://doi.org/10.1016/S0278-4254(03)00037-1

Epps, R.W., \& Cereola, S.J. (2008). Do Institutional Shareholde Services (ISS) Corporate Governance Ratings Reflect a Company's Operating Performance? Critical Perspectives on Accounting, 19(8), 1135-1148. https://doi.org/10.1016/j. cpa.2007.06.007

Estelyi, K.S., \& Nisar, T.M. (2016). Diverse Boards: Why Do Firms Get Foreign Nationals on Their Boards? Journal of Corporate Finance, 39, 174-192. https://doi.org/10.1016/j.jcorpfin.2016.02.006

European Commission. (2012). Women in Decision-Making in the EU. European Union, Brussels. Available in: https://books. google.com/books?hl=en\&lr=\&id=gk5dDwAAQBAJ\&oi=fnd\&pg=PR10\&dq=+European+Commission+Women+in+Decision-Making+in+the+EU+\&ots=SHfP2GrVNI\&sig=SQRxGUuh0DZQv2n5dWLz2QVN2kA

European Commission. (2014). Improving the Gender Balance in Company Boardrooms. European Union, Brussels. Available in: http://ec.europa.eu/newsroom/document.cfm?doc_id=46280.

Fama, E.F., \& Jensen, M.C. (1983). Separation of Ownership and Control. Journal of Law and Economics, 26(2), 301-25. https://doi.org/10.1093/acprof:oso/9780199236978.003.0007

Feng, Y., Nandy, D., \& Tian, Y. (2015). Executive Compensation and the Corporate Spin-Off Decision. Journal of Economics and Business, 77, 94-117. https://doi.org/10.1016/j.jeconbus.2014.09.003

Ferguson, A., Francis, J.R., \& Stokes, D.J. (2003). The Effects of Firm-Wide and Office-Level Industry Expertise on Audit Pricing. The Accounting Review, 78(2), 429-448. https://doi.org/10.2308/accr.2003.78.2.429 
Forbes, D.P., \& Milliken, F.J. (1999). Cognition and Corporate Governance: Understanding Boards of Directors as Strategic Decision-Making Groups. Academy of Management Review, 24(3), 489-505. https://doi.org/10.2307/259138

Francis, J., Huang,A.H., Rajgopal, S., \& Zang, A.Y. (2008). CEO Reputation and Earnings Quality. Contemporary Accounting Research, 25(1), 109-147. https://doi.org/10.1506/car.25.1.5

Francis, J., Khurana, I., \& Pereira, R. (2005). Disclosure Incentives and Effects on Cost of Capital around the World. The Accounting Review, 80(4), 1125-1163. https://doi.org/10.2308/accr.2005.80.4.1125

Francis, J., LaFond, R., Olsson, P.M., \& Schipper, K. (2004). Costs of Equity and Earnings Attributes. The Accounting Review, 79(4), 967-1010. https://doi.org/10.2308/accr.2004.79.4.967

Francis, J., Philbrick, D., \& Schipper, K. (1994). Shareholder Litigation and Corporate Disclosures. Journal of Accounting Research, 32(2), 137-164. https://doi.org/10.2307/2491279

Garcia-Meca, E., \& Sanchez-Ballesta, J. P. (2010). The association of board independence and ownership concentration with voluntary disclosure: A meta-analysis. European Accounting Review, 19(3), 603-627. https://doi.org/10 $.1080 / 09638180.2010 .496979$

Gelb, D.S., \& Zarowin, P. (2002). Corporate Disclosure Policy and the Informativeness of Stock Price. Review of Accounting Studies, (7)1, 33-53. https://doi.org/10.2139/ssrn.235009

Glosten, L., \& Milgram P. (1985). Bid, ask, and transaction prices in a specialist market with hetergeneusly informed traders. Journal of Financial Econimics, 14(1), 71-100.https://doi.org/10.1016/0304-405x(85)90044-3

Goh, B.V., Ng, J., \& Ow-Yong, K. (2008). Corporate Governance and Liquidity: An Exploration of Voluntary Disclosure, Analyst Coverage and Adverse Selection as Mediating Mechanisms. Available at: http://ink.library.smu.edu.sg/soa_research/1

Gordon, E., \& Henry, E. (2005). Related Party Transactions and Earnings Management. Rutgers University. Available at: https://ssrn.com/abstract=612234

Grossman, S., \& Hart, O. (1983). An Analysis of the Principal Agent Problem. Econometrica, 51(1), 7-45. https://doi. org/10.1007/springerreference_2236

Gul, F.A., \& Tsui, J. (2001). Free Cash Flow, Debt Monitoring and Audit Pricing: Further Evidence on the Role of Director Equity Ownership. Auditing: A Journal of Practice \& Theory, 20(2), 71-84. https://doi.org/10.2308/aud.2001.20.2.71

Hambrick, D.C. \& Mason, P.A. (1984). Upper Echelons: The Organization as a Reflection of Its Top Managers. Academy of Management Review, 9, 193-206. https://doi.org/10.2307/258434

Haniffa, R.M., \& Cooke, T.E. (2002). Culture, Corporate Governance and Disclosure in Malaysian Corporations. Abacus, 38(3), 317-349. https://doi.org/10.1111/1467-6281.00112

Hannan, M.T., \& Freeman, J. (1977). The Population Ecology of Organizations. American Journal of Sociology, 82(5), 929964. https://doi.org/10.1007/978-3-319-31816-5_74-1

Haque, F. (2017). The Effects of Board Characteristics and Sustainable Compensation Policy on Carbon Performance of UK Firms. The British Accounting Review, Online-Early, Available at: https://doi.org/10.1016/j.bar.2017.01.001

Harjoto, M., Laksmana, I., \& Lee, R. (2014). Board Diversity and Corporate Social Responsibility. Journal of Business Ethics, 132(4), 641-660. https://doi.org/10.1007/s10551-014-2343-0

Harris, D., \& Helfat, C. (1997). Specificity of CEO Human Capital and Compensation. Strategic Management Journal, 18(11), 895-920. https://doi.org/10.1002/(sici)1097-0266(199712)18:11<895::aid-smj931>3.0.co;2-r

Hassan, O, Romilly, P., Giorgioni, G., \& Power, D. (2009). The Value Relevance of Disclosure: Evidence from the Emerging Capital Market of Egypt. The International Journal of Accounting, 44, 79-102. https://doi.org/10.1016/j.intacc.2008.12.005

Hay, D., Knechel, W.R., \& Ling, H. (2008). Evidence on the Impact of Internal Control and Corporate Governance on Audit Fees. International Journal of Auditing, 12(1), 9-24. https://doi.org/10.1111/j.1099-1123.2008.00367.x

Hayes, R.M., \& Schaefer, S. (2000). Implicit Contracts and the Explanatory Power of Top Executive Compensation for Future Performance. The Rand Journal of Economics, 31(2), 273-293. https://doi.org/10.2307/2601041

Healy, P.M., \& Palepu, K.G. (2001). Information Asymmetry, Corporate Disclosure, and the Capital Markets: A Review of the Empirical Disclosure Literature. Journal of Accounting and Economics, 31(1-3), 405-440. https://doi.org/10.1016/ s0165-4101(01)00018-0

Higgs Report. (2003). Review of the Role and Effectiveness of Non-Executive Directors. Department for Trade and Industry, London. https://doi.org/10.1007/978-3-642-28036-8_101698

Hillman, A.J., \& Dalziel, T. (2003). Boards of Directors and Firm Performance: Integrating Agency and Resource Dependence Perspectives. Academy of Management Review, 28(3), 383-396. https://doi.org/10.2307/30040728 
Hillman, A.J., Cannella, A.A., \& Harris, I.C. (2002). Women and Racial Minorities in the Boardroom: How do Directors Differ? Journal of Management, 28(6), 747-763. https://doi.org/10.1177/014920630202800603

Hitt, M.A., \& Ireland, R.D. (1985). Corporate Distinctive Competence, Strategy, Industry and Performance. Strategic Management Journal, 6, 273-293. https://doi.org/10.1002/smj.4250060307

Hogan, B., \& Jonas, G.A. (2016). The Association between Executive Pay Structure and the Transparency of Restatement Disclosures. Accounting Horizons, 30(3), 307-323. https://doi.org/10.2308/acch-51454

Hui, K.W., \& Matsunaga, S.R. (2015). Are CEOs and CFOs Rewarded for Disclosure Quality? The Accounting Review, 90(3), 1013-1047.https://doi.org/10.2308/accr-50885

Ittner, C.D., Larcker, D.F., \& Rajan, M.V. (1997). The Choice of Performance Measures in Annual Bonus Contracts. The Accounting Review, 72(2), 231-255. Available in: https://www.jstor.org/stable/248554

Jensen, M.C., \& Meckling, W.H. (1976). Theory of the Firm: Managerial Behaviour, Agency Costs and Ownership Structure. Journal of Financial Economics, 3(4), 305-360. https://doi.org/10.1016/0304-405x(76)90026-x

Johnson, J.L., Daily, C.M., \& Ellstrand, A.E. (1996). Boards of Directors: a Review and Research Agenda. Journal of Management, 22(3), 409-438. https://doi.org/10.1016/s0149-2063(96)90031-8

Johnson, S., La-Porta, R., Lopes-de-Silanes, F., \& Shleifer, A. (2000). Tunneling. American Economic Review Papers and Proceedings, 90(2), 22-27. https://doi.org/10.1257/aer.90.2.22

Kalelkar, R., \& Khan, S. (2016). CEO Financial Background and Audit Pricing. The Accounting Horizons, 30(3), 325-339. https://doi.org/10.2308/acch-51442

Kapopoulos, P., \& Lazaretou, S. (2007). Corporate Ownership Structure and Firm Performance: Evidence from Greek Firms. Corporate Governance: An International Review, (15)2, 144-158.https://doi.org/10.1111/j.1467-8683.2007.00551.x

Karamanou, I., \& Vafeas, N. (2005). The Association between Corporate Boards, Audit Committees, and Management Earnings Forecasts: An Empirical Analysis. Journal of Accounting Research, 43(3), 453-486.https://doi.org/10.1111/j.1475679x.2005.00177.x

Kelly, K., \& Seow, J.L. (2016). Investor Reactions to Company Disclosure of High CEO Pay and High CEO-to-Employee Pay Ratio: An Experimental Investigation. Journal of Management Accounting Research, 28(1), 107-125.https://doi. org/10.2308/jmar-51392

Khlif, H., \& Samaha, KH. (2014). Internal Control Quality, Egyptian Standards on Auditing and External Audit Delays: Evidence from the Egyptian Stock Exchange. International Journal of Auditing, 18(2), 139-154.https://doi.org/10.1111/ ijau. 12018

Kim, K.H., Al-Shammari, H.A., Kim, B., and Lee, S.H. (2008). CEO Duality Leadership and Corporate Diversification Behaviour. Journal of Business Research, 62(11), 1173-1180.https://doi.org/10.1016/j.jbusres.2008.10.017

Kothari S.P. (2000). The Role of Financial Reporting in Reducing Financial Risks in the Market. Presented at Building an Infrastructure for Financial Stability Conference (Federal Reserve Bank o Boston), 44, 89-102. Available in: http://citeseerx. ist.psu.edu/viewdoc/download?doi=10.1.1.199.6241\&rep=rep1\&type=pdf

Koyuncu, B., Firfiray, S., Claes, B., \& Hamori, M. (2010). CEOs with a Functional Background in Operations: Reviewing their Performance and Prevalence in the Top Post. Human Resource Management, 49(5), 869-882. https://doi.org/10.1002/ hrm.20389

Krishnan, G., \& Wang, C. (2015). The Relation between Managerial Ability and Audit Fees and Going Concern Opinions. Auditing: A Journal of Practice \& Theory, 34(3), 139-160. https://doi.org/10.2308/ajpt-50985

Lang, M., \& Lundholm, R. (1993). Cross-sectional determinants of analyst ratings of corporate disclosures. Journal of Accounting Research, 246-271. https://doi.org/10.2307/2491273

Lang, M.H., \& Lundholm, R.J. (2000). Voluntary Disclosure and Equity Offerings: Reducing Informatio Asymmetry or Hyping the Stock? Contemporary Accounting Research, 17(4), 623-662.https://doi.org/10.1092/9n45-f0jx-axvw-lbwj

Lee, S., Matsunaga, S.R., \& Park, C.W. (2012). Management Forecast Accuracy and CEO Turnover. The Accounting Review, 87(6), 2095-2122.https://doi.org/10.2308/accr-50220

Leftwich, R., Watts, R., \& Zimmerman, J. (1981). Voluntary Corporate Disclosure: The Case of Interim Reporting. Journal of Accounting Research, 19, 50-77.https://doi.org/10.2307/2490984

Li, J., Pike, R., \& Haniffa, R. (2008). Intellectual Capital Disclosure and Corporate Governance Structure in UK Firms. Accounting and Busines Research, 38(2), 137-159.https://doi.org/10.1080/00014788.2008.9663326 
Liao, L., Luo, L., \& Tang, Q. (2015). Gender Diversity, Board Independence, Environmental Committee and Greenhouse Gas Disclosure. The British Accounting Review, 47 (4), 409-424. https://doi.org/10.1016/j.bar.2014.01.002

Lim, S., Matollcky, Z., \& Chow, D. (2007). The Association between Board Composition and Different Types of Voluntary Disclosure. European Accounting Review, 16(3), 555-583.https://doi.org/10.1080/09638180701507155

Ma, X., Yiu, D.W., \& Zhou, N. (2014). Facing Global Economic Crisis: Foreign Sales, Ownership Groups, and Corporate Value. Journal of World Business, 49(1), 87-100. https://doi.org/10.1016/j.jwb.2013.02.002

Madhani, P. (2009). Role of Disclosure and Transparency in Financial Reporting. The Accounting World, 7(6), 63-66. https:// doi.org/10.14419/ijaes.v3i1.4549

Manetti, G., \& Toccafondi, S. (2012). The Role of Stakeholders in Sustainability Reporting Assurance. Journal of Business Ethics, 107(3), 363-377.https://doi.org/10.1007/s10551-011-1044-1

Matsunaga, S.R., Wang, S., \& Yeung, P.E. (2013). Does Appointing a Former CFO as CEO Influence a Firm's Accounting Policies? Working Paper University of Oregon.

Miller, T., \& Triana, M.D.C. (2009). Demographic Diversity in the Boardroom: Mediators of the Board Diversity-Firm Performance Relationship. Journal of Management Studies, 46(5), 755-786. https://doi.org/10.1111/j.14676486.2009.00839.x

Mirrlees, J. (1976). The Optimal Structure of Incentives and Authority within an Organisation. Bell Journal of Economics, 7(1), 105-131. https://doi.org/10.2307/3003192

Mizruchi, M.S. (1983). Who Controls Whom? An Examination of the Relation between Management and Boards of Directors in Large American Corporations. Academy of Management Review, 8(3), 426-435.https://doi.org/10.2307/257831

Nagar, V., Nanda, D., \& Wysocki, P. (2003). Discretionary Disclosure and Stock-Based Incentives. Journal of Accounting and Economics, 34(1-3), 283-309. https://doi.org/10.1016/s0165-4101(02)00075-7

Nanda, V., \& Onal, B. (2016). Incentive contracting when boards have related industry Expertise. Journal of Corporate Finance, 41, 1-22. https://doi.org/10.1016/j.jcorpfin.2016.08.014

Navissi, F., Sridharan, V.G., Khedmati, M., Lim, E.K.Y., \& Evdokimov, E. (2016). Business Strategy, Over (Under) Investment and Managerial Compensation. Journal of Management Accounting Research. Online-Early, Available at: https://doi. org/10.2308/jmar-51537

Patelli, L., \& Prencipe, A. (2007). The Relationship between Voluntary Disclosure and Independent Directors in the Presence of a Dominant Shareholder. European Accounting Review, 16(1), 5-33. https://doi.org/10.1080/09638180701265820

Petersen, C., \& Plenborg, T. (2006). Voluntary Disclosure and Information Asymmetry in Denmark. Journal of International Accounting, Auditing and Taxation, 15(2), 127-149. https://doi.org/10.1016/j.intaccaudtax.2006.08.004

Pfeffer J. (1981). Power in Organizations. Marshfield, MA: Pitman.

Pfeffer, J. (1972). Size and Composition of Corporate Boards of Directors: the Organization and its Environment. Administrative Science Quarterly, 17(2), 218-228. https://doi.org/10.2307/2393956

Pfeiffer, G.M., \& Shields, T.W. (2015). Performance-Based Compensation and Firm Value-Experimental Evidence. Accounting Horizons, 29(4), 777-798. https://doi.org/10.2308/acch-51143

Rhoades, D.L., Rechner, P.L., \& Sudramurthy, C. (2001). A Meta-Analysis of Board Directorship Structure and Financial Performance: Are Two Heads Better than One? Corporate Governance: An International Review, 9(4), 311-19.https:// doi.org/10.1111/1467-8683.00258

Rindova, V.P. (1999). What Corporate Boards have to do with Strategy: A Cognitive Perspective. Journal of Management Studies, 36(7), 953-975.https://doi.org/10.1111/1467-6486.00165

Rose, N., \& Shepard, A. (1997). Firm Diversification and CEO Compensation: Managerial Ability or Executive Entrenchment? RAND Journal of Economics, 28(3), 489-514. https://doi.org/10.3386/w4723

Samaha, K., Dahawy, K., Abdel-Meguid, A., \& Abdallah, S. (2012). Propensity and Comprehensiveness of Corporate Internet Reporting in Egypt: Do Board Composition and Ownership Structure Matter? International Journal of Accounting and Information Management, 20(2), 142-170. https://doi.org/10.1108/18347641211218452

Samaha, Kh., Khlif, H., \& Hussainey, Kh. (2015). The Impact of Board and Audit Committee Characteristics on Voluntary Disclosure: A Meta-Analysis. Journal of International Accounting, Auditing and Taxation, 24, 13-28. https://doi. org/10.1016/j.intaccaudtax.2014.11.001 
Sanders, W.M.G., \& Carpenter, M.A. (1998). Internationalization and Firm Governance: The Roles of CEO Compensation, Top Team Composition, and Board Structure. The Academy of Management Journal, 41(2), 158-178. https://doi. org $/ 10.5465 / 257100$

Sariol,A.M., \& Abebe, M.A. (2017). The Influence of CEO Power on Explorative and Exploitative Organizational Innovation. Journal of Business Research, 73, 38-45. https://doi.org/10.1016/j.jbusres.2016.11.016

Senderovitz, M., Klyver, K., \& Steffens, P. (2016). Four Years On: Are the Gazelles Still Running? A Longitudinal Study of Firm Performance after a Period of Rapid Growth. International Small Business Journal, 34(4), 391-411. https://doi. org/10.1177/0266242614567483

Shin, H., \& Park, Y.S. (1999). Financing Constraints and Internal Capital Markets: Evidence from Korean Chaebols. Journal of Corporate Finance, 5(2), 169-194. https://doi.org/10.1016/s0929-1199(99)00002-4

Shleifer, A., \& Robert W.V. (1997). A Survey of Corporate Governance. The Journal of Finance, 52(2), 737-783. https://doi. org/10.3386/w5554

Simunic, D.A., \& Stein, M.T. (1996). The Impact of Litigation Risk on Audit Pricing: A Review of the Economics and the Evidence. Auditing: A Journal of Practice \& Theory, 15, 119-134. Available in: https://search.proquest.com/openview/30cbb48fb24bb1ec1422a7351cc29dec/1?pq-origsite $=$ gscholar $\& \mathrm{cbl}=31718$

Sloan, R.G. (1993). Accounting Earnings and Top Executive Compensation. Journal of accounting and Economics, 16(1-3), 55-100. https://doi.org/10.1016/0165-4101(93)90005-z

Srinidhi, B., Gul, F.A., \& Tsui, J. (2011). Female Directors and Earnings Quality. Contemporary Accounting Research, 28(5), 1610-1644. https://doi.org/10.1111/j.1911-3846.2011.01071.x

Stevenson, W.B., \& Radin, R.F. (2009). Social Capital and Social Influence on the Board of Directors. Journal of Management Studies, 46(1), 16-44. https://doi.org/10.1111/j.1467-6486.2008.00800.x

Terjesen, S., Sealy, R., \& Singh, V. (2009).Women Directors on Corporate Boards: A Review and Research Agenda. Corporate Governance, 17(3), 320-337. https://doi.org/10.1111/j.1467-8683.2009.00742.x

Triana, M.D.C., Miller, T.L., \& Trzebiatowski, T.M. (2013). The Double-Edged Nature of Board Gender Diversity: Diversity, Firm Performance, and the Power of Women Directors as Predictors of Strategic Change. Organization Science, 25(2), 609-632. https://doi.org/10.1287/orsc.2013.0842

Tucker, J.W., \& Zarovin, P.A. (2006). Does Income Smoothing Improve Earning Informativness? The Accounting Review, 81(1). 252-270. https://doi.org/10.2308/accr.2006.81.1.251

Vafeas, N., \& Waeglein, J.F. (2007). The Association between Audit Committees, Compensation Incentives, and Corporate Audit Fees. Review of Quantitative Finance and Accounting 28(3), 241-255. https://doi.org/10.1007/s11156-006-0012-9

Wang, J., \& Dewhirst, H.D. (1992). Boards of Directors and Stakeholder Orientation. Journal of Business Ethics, 11(2), 11521. https://doi.org/10.1007/bf00872318

Welker M. (1995). Disclosure Policy, Information Asymmetry, and Liquidity in Equity Markets. Contemporary Accounting Research, 11(2), 801-827. https://doi.org/10.1111/j.1911-3846.1995.tb00467.x

Westphal, J.D. (1999). Collaboration in the Boardroom: Behavioral and Performance Consequences of CEO-Board Social Ties. Academy of Management Journal, 42(1), 7-24. https://doi.org/10.2307/256871

World Bank. (1998). East Asia: The Road to Recovery. Washington DC

World Bank. (2009). Report on the Observance of Standards and Codes: Accounting and Auditing. Arab Republic of Egypt, August.

Young, M.N., Ahlstrom, D., Bruton, G.D., \& Chan, E.S. (2001). The Resource Dependence, Service and Control Functions of Board of Directors in Hong Kong and Taiwanese firms. Asia Pacific Journal of Management, 18(2), 223-244. https://doi. org/10.1023/A:1010624109010

Zubaidah, Z.A., Nurmala, M.K., \& Jusoff, K. (2009). Board Structure and Corporate Performance in Malaysia. International Journal of Economics and Finance, 1(1), 150-164. https://doi.org/10.5539/ijef.v1n1p150 